\title{
An Eclectic Approach to Loyalty-Promoting Instruments in Corporate Law: Revisiting Hirschman's Model of Exit, Voice, and Loyalty
}

\author{
Bart Bootsma*
}

\begin{abstract}
This essay analyses the shareholder role in corporate governance in terms of Albert Hirschman's Exit, Voice, and Loyalty. The term 'exit' is embedded in a law \& economics framework, while 'voice' relates to a corporate constitutional framework. The essay takes an eclectic approach and argues that, in order to understand the shareholder role in its full breadth and depth, the corporate law \& economics framework can 'share the analytical stage' with a corporate constitutional framework. It is argued that Hirschman's concept of 'loyalty' is the connecting link between the corporate law \& economics and corporate constitutional framework. Corporate law is perceived as a Janus head, as it is influenced by corporate law \& economics as well as by corporate constitutional considerations. In the discussion on the shareholder role in public corporations, it is debated whether corporate law should facilitate loyalty-promoting instruments, such as loyalty dividend and loyalty warrants. In this essay, these instruments are analysed based on the eclectic approach. It is argued that loyalty dividend and warrants are law \& economics instruments (i.e. financial incentives) based on corporate constitutional motives (i.e. promoting loyalty in order to change the exit/voice mix in favour of voice).
\end{abstract}

Keywords: Eclecticism, corporate law \& economics, corporate constitutionalism, loyalty-promoting instruments

The unhappy shareholder exits only by finding someone else to take his or her place. This substitution does not eliminate the impact of exit, but it greatly reduces it. At the same time, the structure and regulation of equity markets today overwhelmingly emphasise exit over voice and this has often led to shareholder engagement of superficial character and low quality. We believe equity markets mill function more effectively if there are more

\footnotetext{
PhD candidate in the corporate law department at Erasmus School of Law, Erasmus University Rotterdam. Email: bootsma@law.eur.nl. The research for this article has been supported by a grant from the Netherlands Organisation for Scientific Research (NWO) in the Open Competition in the Social Sciences 2010. The author is grateful to Ellen Hey, Klaus Heine, Michael Faure, Matthijs de Jongh and two anonymous reviewers for their constructive comments and suggestions. The usual disclaimer applies.
}

trust relationships which are based on voice and fewer trading relationships emphasising exit. ${ }^{1}$

\section{Introduction}

In this article, Albert Hirschman's insights regarding the interaction of exit, voice, and loyalty are used to analyse the shareholder role in corporate governance. ${ }^{2}$ Hirschman, who wrote his original Exit, Voice, and Loyalty more than forty years ago, has had an enormous impact throughout and beyond the social sciences. ${ }^{3}$ The model claims validity for analysing human behaviour in a number of different situations, ranging from organisations through to markets and to states. The model is also applicable to shareholders in public corporations. ${ }^{4} \mathrm{Nev}-$ ertheless, relatively few corporate governance scholars have used Hirschman's model to analyse the shareholder role in corporate governance. ${ }^{5}$ In previous research, shareholders' exit and voice have largely been studied independently, without considering the interaction

1. The Kay Review of UK Equity Markets and Long-Term Decision Making, Final Report [hereinafter Kay Review], <http://www.bis.gov.uk/ assets/ biscore/ business -law/ docs/ k/ 12 -917 -kay -review -of -equity markets-final-report.pdf> (last visited 31 Jan. 2013), at 21 (2012).

2. A.O. Hirschman, Exit, Voice, and Loyalty, Responses to Decline in Firms, Organizations, and States (1970).

3. See for an analysis on the impact of Hirschman's work, e.g., L. Meldolesi, Discovering the Possible: The Surprising World of Albert O. Hirschman (1995). Albert Hirschman died on 10 December 2012 at the age of 97. See for an obituary the Schumpeter Column in The Economist, 'Exit Albert Hirschman, A Great Lateral Thinker Died on December 10th', <http://www.economist.com/news/business/21568708-great-lateralthinker-died-december-10th-exit-albert-hirschman> (last visited 31 Jan. 2013). See for further biographical details J. Adelman, Worldly Philosopher: The Odyssey of Albert O. Hirschman (2013).

4. Hirschman (1970), above n. 2, at 46. The focus in this article is on corporations whose shares are publicly traded. With 'closed' corporations, shareholder loyalty can often be assumed. The problem (see infra Section 2) comes when exit is a possibility, which is especially the case in public corporations.

5. P.C. Kostant, 'Exit, Voice and Loyalty in the Course of Corporate Governance and Counsel's Changing Role', Journal of Socio-Economics 28 (1999), at 204. See for some notable exceptions L. Lowenstein, What's Wrong With Wall Street (1988), J.C. Coffee, 'Liquidity Versus Control: The Institutional Investor as Corporate Monitor', 91 Columbia Law Review 1277 (1991). 
between exit and voice. ${ }^{6}$ For instance, the Kay Reviem refers to exit and voice in its analysis of UK equity markets, while Hirschman's concept of loyalty is lacking in the review.?

Although Hirschman's model has a wide application range, the statements in this article are limited to the corporate governance context. The concepts of exit and voice are linked to theoretical frameworks about corporate governance. Exit, which Hirschman calls an 'impersonation' of economics, is embedded in a corporate law \& economics framework. Voice, which Hirschman regards as an impersonation of politics, is connected to a corporate constitutional framework. ${ }^{8}$ It is argued that, in order to understand the shareholder role in corporate governance in its full breadth and depth, the two theoretical frameworks are needed. This implies that the two theoretical frameworks are combined in an eclectic approach. Eclectic is defined as 'selecting what appears to be best in various doctrines, methods, or styles'. ${ }^{9}$ According to this definition, when it proves not to be particularly suitable to analyse certain issues within the context of one theoretical framework, an analysis should be complemented by a theoretical framework that is more appropriate. ${ }^{10}$

Law \& economics is often criticised for claiming to be the sole mode of analysis. ${ }^{11}$ Several authors have argued that there is not one universal theoretical framework for corporate governance. ${ }^{12}$ However, if we criticise corporate law \& economics as the only or ultimate mode of analysis, a theoretical framework has to be presented that serves as counterbalance for the law \& economics framework. ${ }^{13}$ I suggest that a corporate constitutional framework can perform this task. Based on the eclectic approach, ${ }^{14}$ corporate constitutionalism is not viewed as a replacement for but as complementary to corporate law $\&$ economics. The main focus of the analysis concerns how corporate constitutionalism complements corporate law \& economics. Alessandra Arcuri concluded in a previous issue of Erasmus Lam Reviem that the eclectic approach is suitable for an economic analysis of law. She showed convincingly that law $\&$ economics scholars to a certain extent already practice eclecticism. ${ }^{15}$

In Section 2 of this article, two problems related to the shareholder role in corporate governance are identified: (i) short-termism and (ii) lack of engagement in corporate governance. Section 3 conceptualises the corporate

12. See, e.g., S. Bottomley, The Constitutional Corporation: Rethinking Corporate Governance (2007), at 12 ('The corporate world is too complex and too variable for any single theory or discipline to be able to supply all of the answers to all of the problems of corporate governance. There are aspects of corporate life for which economic theories are well-suited but, equally, there are other aspects for which we need a different framework, another option of the conceptual menu. Economics can share the analytical stage with other approaches [emphasis added]', note that I have borrowed the expression of 'sharing the analytical stage' in the abstract of this article); Timmerman (2007), above $n$. 11 , at 328 (' $[\mathrm{W}] \mathrm{e}$ need a corporate law regime that is more than just economically efficient. There is not one universal model of corporate law, particularly where the interests and visions of people differ greatly within our society and from society to society [emphasis added]'), Arcuri, above n. 10, at 74 ('[D]efending that the mainstream paradigm [of law \& economics] is too narrow does not imply a rejection of rational choice theory; rather, it is suggested that other theories may well enrich the analytical apparatus of L\&E by offering new venues for studying problems when the application of rational choice theory would either be unuseful and uninteresting or even fallacious [emphasis added]').

13. Consistent with his professional background as Advocate-General at Supreme Court of the Netherlands (Hoge Raad), Timmerman (2007), above n. 11 emphasises the role of courts and focuses on reasonableness and fairness in concrete cases. Hijink criticises the striving for reasonableness and fairness as an empty, meaningless goal of corporate law. See J.B.S. Hijink, Publicatieverplichtingen voor Beursvennootschappen (2010), at 88 . The corporate constitutional framework presented provides - in order to counterbalance the corporate law \& economics framework - a theoretical basis for notions of reasonableness and fairness. See infra Section 4

14. Timmerman (2007), above n. 11 speaks about a 'pluralistic' approach and Korobkin and Ulen argue for 'creating a collection of situation-specific minitheories useful in the analysis of discrete legal problems'. See R.B. Korobkin and T.S. Ulen, 'Law and Behavioral Science: Removing the Rationality Assumptions from the Law and Economics', 88 California Law Review 1051 (2000).

15. Arcuri, above n. 10, at 60 refers to the work of Adam Smith, as cited by Jacob Viner: 'In these days of contending schools, each of them with the deep, though momentary, conviction that it, and it alone, knows the one and only path to economic truth, how refreshing it is to return to The Wealth of Nations with its eclecticism, its good temper, its common sense, and its willingness to grant that those who saw things differently from itself were only partly wrong [emphasis added]'. See J. Viner, 'Adam Smith and Laissez Faire', 35 The Journal of Political Economy 198 (1927), at 232, quoted in Arcuri. Arcuri, above n. 10, at 63-64 considers not only Smith's Wealth of Nations of value for law \& economics but his entire oeuvre, including The Theory of Moral Sentiments and Lectures on Jurisprudence. 
governance activities of shareholders (i.e. shareholder activism) in terms of Hirschman's model. The problems identified in Section 2 are analysed in terms of Hirschman's model as (i) an excessive focus on exit and (ii) a subsequent lack of voice. Section 4 explains the conceptual differences with respect to corporate law and corporate governance between the corporate law \& economics framework (with its emphasis on exit) and the corporate constitutional framework (with its emphasis on voice), which serves as the onset for Section 5. Section 5 draws a comparative evaluation of shareholder activism by engaging both with corporate law \& economics and corporate constitutionalism. The comparative evaluation demonstrates that the two theoretical frameworks highlight different aspects of the same situation. The theoretical frameworks can be viewed as two sides of a coin, as a representation of the Janus head of corporate law. ${ }^{16}$ The differences are not black and white; they are to be regarded as differences in emphasis. To give an example, although a corporate law \& economics framework puts more emphasis on exit, it is not to say that voice is completely overlooked or disregarded. ${ }^{17}$

Once the differences in emphasis with respect to the shareholder role in corporate governance highlighted by the corporate law \& economics and corporate constitutional framework have been outlined, Section 6 offers in order to provide a complete understanding of shareholder activism - an integrated analysis based on the two theoretical frameworks. If corporate law \& economics and corporate constitutionalism are viewed as complementary theoretical frameworks, they must be somehow related. Hirschman's concept of loyalty is used as the connecting link between corporate law $\&$ economics and corporate constitutionalism.

Hirschman's work is hard to pigeonhole. To mention a few opinions, he has been characterised as economist, political scientist, sociologist, historian and moral philosopher, but lawyer has not been among these classifi-

16. See on the Janus head of corporate law L. Timmerman, Gedragsrecht, Belangenpluralisme en Vereenvoudiging van het Vennootschapsrecht Wat Moet Dwingend Blijven in het Vennootschapsrecht van de Toekomst? (2004), at 12; B.F. Assink, De Januskop van het Ondernemingsrecht - Over Faciliëren en Reguleren van Ondernemerschap (2010). See also M.A. Eisenberg, 'Corporate Law and Social Norms', 99 Colum bia Law Review 1253 (1999), at 1253 ('Corporate law serves both to facilitate and to regulate the conduct of the corporate enterprise').

17. Cf. Bottomley, above n. 12. See for the label 'corporate constitutionalism' already R.S.F. Eells, The Government of Corporations (1962). See for voice from a financial economics perspective, e.g., Edmans, above $n$. 6, A. Edmans, V.W. Fang and E. Zur, 'The Effect of Liquidity on Governance', 26 The Review of Financial Studies 6 (2013), and A. Edmans and G. Manso, 'Governance Through Trading and Intervention: A Theory of Multiple Blockholders', 24 The Review of Financial Studies 7 (2011). cations. ${ }^{18}$ To my knowledge, linking Hirschman's concept of loyalty to the corporate legal domain is a novelty. ${ }^{19}$ The construction of loyalty as the variable that influences the balance between exit and voice highlights the importance of corporate law. Where exit is the domain of economists and voice is the domain of political scientists, loyalty relates to the legal domain. ${ }^{20} \mathrm{Sec}-$ tion 6 shows how corporate law balances the diverging interests of exit and voice.

Stressing the importance of loyalty as mediating variable between exit and voice has important policy implications. Most shareholders are not intrinsically loyal to the corporation. ${ }^{21}$ It is argued that loyalty can be gained more easily if it is rewarded. ${ }^{22}$ Corporate law can facilitate loyalty-promoting instruments, such as loyalty divi-

18. Hirschman described himself as a 'trespasser' as he delved deeply into fields outside his own profession of economics. See, e.g., A.O. Hirschman, Essays in Trespassing: Economics to Politics and Beyond (1981). In a 1993 interview, Hirschman remarked, 'The idea of trespassing is basic to my thinking. Attempts to confine me to a specific area make me unhappy. When it seems that an idea can be verified in another field, then I am happy to venture this direction. I believe this is a simple and useful way of discovering "related" topics.' Quote taken from <http://www.ssrc.org/hirschman/about> (last visited 31 Jan. 2013). In The Economist, above $\mathrm{n} .3$ it is suggested that this 'trespassing' might be the reason why Hirschman was never awarded the Nobel prize in economics. See also Adelman, above n. 3, at 613-616.

19. But see Kostant, above n. 5 on the role of corporate lawyers in enhancing voice and loyalty.

20. This is to say that the legal domain puts much emphasis on loyalty, see infra Section 6.1. This is not to say that loyalty is completely overlooked or disregarded by the other domains. For instance, there may also be an economic case for shareholder loyalty, on the basis of the role that a long-term commitment by shareholders can have in promoting firmspecific investments by other stakeholders. Also, loyal shareholders, as insiders, may be able to exercise monitoring more effectively than outsiders can. See on the balance between internally oriented and externally oriented corporate governance V.V. Acharya, S.C. Myers and R.G. Rajan, 'The Internal Governance of Firms', 66 The Journal of Finance 3 (2011).

21. Bolton and Samama, above n. 7, at 2 ('[F]or the typical shareholder, there is no real sense of loyalty to the company'). Owners of family businesses are an exception to this point, as they want to preserve the corporation for the next generation. See for empirical evidence that family business focus on resilience more than short-term performance N. Kachaner, G. Stalk and A. Bloch, 'What You Can Learn From Family Business', Harvard Business Review 11 (2012). Furthermore, there are countries were shareholder loyalty might be more the norm than the exception, even for listed corporations. See, e.g., on the case of Japan J. Buchanan, D.H. Chai and S. Deakin, Hedge Fund Activism in Japan: The Limits of Shareholder Primacy (2011). Therefore, in this article I will mainly refer to the UK, the US, and the Netherlands. These are countries with a great emphasis on exit. See for the UK the quote taken from the Kay Review, above n. 1.

22. Bolton and Samama, above n. 7, at 2. See also Kay Review, above n. 1, at 5 ('Incentives matter: not because, as some people crudely think, financial rewards are the only human motivation - although there are some people of whom that is true, and many of them are to be found in the financial sector'); Advocate-General Timmerman makes a similar point in his conclusion for the DSM case, Supreme Court of the Netherlands 14 December 2007, NJ 2008, 105 (DSM), at 3.58 
dends and loyalty warrants. ${ }^{23}$ These instruments - and, more specifically, how they relate to corporate law \& economics and corporate constitutionalism - are discussed in Section 7. Finally, Section 8 concludes with a summary of the lessons on loyalty-promoting instruments that have been learned from Hirschman's model.

\section{Shareholder Role in Corporate Governance}

In the early 1990s, Bernard Black observed that the shareholder role was again on the US agenda. ${ }^{24}$ Since that time, the discussion on the role of shareholders in corporate governance has remained prominently at the forefront. This is not only the case in the US but also on the other side of the Atlantic. In the US, the discussion orientates around the concept of 'shareholder democra$c y^{\prime}$ (i.e. shareholder empowerment) ${ }^{25}$ while in the UK, the concept of 'stewardship ${ }^{26}$ takes a central place in the discussion on the role of (institutional) shareholders. In the Netherlands, the concept of 'citizenship of shareholders' has been introduced. ${ }^{27} \mathrm{~A}$ considerable number

23. Although much of the conclusions also hold for loyalty voting rights, these instruments are not explicitly included in the analysis. I believe that loyalty dividend and loyalty warrants have additional benefits over loyalty voting right as they provide shareholders with a direct financial incentive. In the recent merger between $\mathrm{CNH}$ Global NV and Fiat Industrial SpA, loyalty voting rights were actually awarded. See for more information the websites of these companies <www.cnh.com> and <www. fiatindstrial.com $>$ and $M$. van Olffen, 'Nederlandse Loyaliteitsaandelen met een Frans Sausje', Ondernemingsrecht 67 (2013).

24. B.S. Black, 'Agents Watching Agents: The Promise of Institutional Investor Voice', 39 UCLA Law Review 4 (1992), at 812.

25. See for a discussion on shareholder democracy, e.g., L.A. Bebchuk, 'The Case for Increasing Shareholder Power', 118 Harvard Law Review 3 (2005), S.M. Bainbridge, 'Director Primacy and Shareholder Disempowerment', 119 Harvard Law Review 6 (2006), and L. Strine, 'Towards a True Corporate Republic: A Traditionalist Response to Lucian's Solution for Improving Corporate America', Harvard Law and Economics Discussion Paper, No. 541 (2006) and W.W. Bratton and M.L. Wachter, 'The Case Against Shareholder Empowerment', 158 University of Pennsy/vania Law Review (2010).

26. Financial Reporting Council, The UK Stewardship Code, first published July 2010 and last revised September 2012, <http://www.frc.org.uk/ Our-Work/Codes-Standards/Corporate-governance/UK-StewardshipCode.aspx> (last visited 31 Jan. 2013). See for the Netherlands also Eumedion, Best Practices for Engaged Share-Ownership Intended for Eumedion Participants, June 2011, <http:// www .eumedion .nl/ en/ public/knowledgenetwork/best-practices/best_practices-engaged-share -ownership.pdf> (last visited 31 Jan. 2013).

27. Dutch Corporate Governance Code Monitoring Committee, Second Report on Compliance with the Dutch Corporate Governance Code, December 2010, <http://www.commissiecorporategovernance.nl/ download/?id=579\&download $=1>$ (last visited 31 Jan. 2013), at 10 ('As noted in the preamble to the Code, unlike the management board and the supervisory board, shareholders are not, in principle, guided exclusively by the interests of the company and its business. For example, shareholders can give priority to their own interests, provided they act in accordance with the principles of reasonableness and fairness. This means that if shareholders exercise their rights, they may still be accountable. In other words, they still have responsibilities. The Monitoring Committee uses the expression "citizenship of the shareholder" to describe the actual discharge of such responsibilities by shareholders. This includes, for example, the willingness to enter into a dialogue with the company and fellow shareholders when the occasion arises'). of normative claims have been made about the role of shareholders in corporate governance: shareholders should act more as owners, ${ }^{28}$ shareholders should adopt a long-term perspective, ${ }^{29}$ and fiduciary duties should be imposed on shareholders, ${ }^{30}$ and so on.

Over the past two decades, institutional shareholders have not fulfilled the promise of their shareholder oversight function. ${ }^{31}$ In the period 2001-2003, there was a governance crisis after a wave of corporate scandals involving, among others, Enron, WorldCom, and Tyco in the US, and Royal Ahold and Royal Dutch Shell in the Netherlands. The governance crisis was followed by a severe financial crisis in 2007-2008, which showed that governance questions persisted. Jaap Winter identifies two complaints against shareholders and their role in these crises: (i) excessive focus of shareholders on shortterm proceeds (i.e. short-termism) and (ii) insufficient engagement of shareholders in corporate governance. ${ }^{32}$ The two complaints are related. ${ }^{33}$

To illustrate these problems, I include some basic empirical facts regarding short-termism and the lack of engagement of shareholders. In the US, the UK and Dutch stock markets, there has been a trend towards shorter average holding periods of shares. For instance, in the UK, the average holding period of shares has fallen from around five years in the mid-1960s to around two years in the 1980s. Around 2000, the average share-

28. A Review of Corporate Governance in UK Banks and Other Financial Industry Entities, Final Recommendations [hereinafter Walker Review], November 2009, <http://webarchive.nationalarchives.gov.uk/+/http:/ www.hm-treasury.gov.uk/d/walker_review_261109.pdf> (last visited 31 Jan. 2013), at 72 (' $[B]$ oard and director shortcomings ... would have been tackled more efficiently had there been more vigorous scrutiny and persistence by major investors acting as owners [emphasis added]').

29. Kay Review, above n. 1

30. R.S. Karmel, 'Should a Duty to the Corporation Be Imposed on Institutional Investors?', 60 Business Lawyer 1 (2004), I. Anabtawi and L.A. Stout, 'Fiduciary Duties for Activist Shareholders', 60 Stanford Law Review 1255 (2008).

31. It is important to note that there are different types of shareholders, see infra Section 3. The term 'institutional shareholders' refers to pension funds, insurance companies, mutual funds, and so on. The focus on institutional shareholders is justified, as these shareholders hold the majority of shares in listed corporations and manage other people's money.

32. J.W. Winter, 'The Financial Crisis: Does Good Corporate Governance Matter and How to Achieve It?', Duisenberg School of Finance Policy Paper, No. 14 [hereinafter Winter (2011a)], <http://papers.ssrn.com/ sol3/papers.cfm?abstract_id=1972057> (last visited 31 Jan. 2013), at 3. See on the first complaint (i.e., short termism) also A.G. Haldane and R. Davies, 'The Short Long', 29th Société Universitaire Européene de Recherches Financières Colloquium: New Paradigms in Money and Finance?, May 2011, and D. Barton, 'Capitalism for the Long Term', 85 Harvard Business Review 3 (2011).

33. See also J.W. Winter, 'Shareholder Engagement and Stewardship, the Realities and Illusions of Institutional Share Ownership' [hereinafter Winter (2011b)], <http://papers.ssrn.com/sol3/papers.cfm? abstract_id=1867564> (last visited 31 Jan. 2013). 
holder period was just over a year, and by 2007, it had fallen to around seven and a half months. ${ }^{34}$

The average attendance at annual shareholder meetings provides an indication of the engagement of shareholders. In the Netherlands, shareholder participation, measured as the number of votes cast at annual general meetings, decreased in 2013 for the first time in a number of years, to $62.7 \% .^{35}$ This was due to the rather low attendance rates at three Dutch listed companies: KPN, Imtech and PostNL. Eumedion gives the following explanation:

The cause of the lower attendance is probably connected with changes in the shareholder structure at the three companies. Investors with a long-term horizon are inclined to sell shares in those companies where the (dividend) prospects are poor. In the 26 April 2013 edition of the Dutch newspaper Het Financieele Dagblad, KPN CFO Hageman said, for example, that 'You see a fem more short-term shareholders, a few more hedge funds than there used to be ...' The[se] shareholders may be of the activist kind or may just have little interest in voting at AGMs. It is pointed out in the same article, that KPN is one of the most popular European shares for short sellers. Approximately $17.5 \%$ of the shares were on loan at the time of the record date for the KPN AGM. Approximately $70 \%$ of the shares that could be borrowed, were, in fact, out on loan at that time. These shares are usually lent by long-term investors; investors who generally do vote. The parties that borrow the shares will usually be 'young' investors, who are less inclined to vote the shares they have recently acquired. ${ }^{36}$

Some authors deny that there is a problem of this kind. ${ }^{37}$ For instance, Bebchuk complains about a lack of empirical evidence on short-termism. ${ }^{38}$ However, he does not refer to available empirical studies regarding

34. See for more statistics A.G. Haldane, 'Patience and Finance', Oxford China Business Forum, at 30 (2010) and Bolton and Samama, above $\mathrm{n}$. 7, at 3. De Roon and Slager find that the average shareholder period of five Dutch institutional investors was roughly three and a half years. See F. de Roon and A. Slager, The Duration and Turnover of Dutch Equity Ownership, A Case Study of Dutch Institutional Investors, Study commissioned by Eumedion (2012). Nevertheless, their small sample is not representative for all institutional shareholdings, let alone for the whole shareholder base.

35. Eumedion, Evaluation Report of the 2013 Dutch Proxy Season, $<$ www.eumedion.nl>, at 1 (2013)

36. Eumedion (2013), above n. 35, at 3-4

37. Cf. L.E. Strine, 'One Fundamental Corporate Governance Question We Face: Can Corporations Be Managed for the Long Term Unless Their Powerful Electorates Also Act And Think Long Term?', 66 Business Lawyer 1, at 2 (2010) ('[T]oo many observers of corporate governance - and dare I say it, too many institutional investors - deny that there is a problem of this kind at all'). See, e.g., L.A. Bebchuk, 'The Myth That Insulating Boards Serves Long-Term Value', 113 Columbia Law Review (2013, forthcoming), M.J. Roe, 'Corporate Short Termism - in the Boardroom and in the Courtoom', 68 Business Lawyer 4 (2013, forthcoming) and M. Kahan and E.B. Rock, 'Hedge Funds in Corporate Governance and Corporate Control', 155 University of Pennsylvania Law Review 1021 (2007)

38. Bebchuk (2013), above n. 37, at 27. short-termism. ${ }^{39}$ Bebchuk creates a distinction between shareholder power advocates - to which camp he belongs - and board insulation advocates. Bebchuk states that the body of empirical evidence supports his view that 'shareholder engagement, and arrangements that facilitate it, serve the long-term interests of companies and their shareholders'. ${ }^{40}$ In Bebchuk's opinion, this view contradicts the view of 'insulation advocates [who] believe that increased shareholder power, voice, or involvement is detrimental to long-term value'. ${ }^{41}$ In my opinion, the distinction between shareholder power advocates and board insulation advocates is false. Bebchuk refers to loyalty rewards as board insulation instruments. ${ }^{42}$ In this article, I argue for a more nuanced view. In my opinion, loyalty-promoting instruments take a middle-position between shareholder power and board insulation. In the next section, I distinguish between different types of shareholders and different forms of shareholder activism. The key question is which shareholders are empowered: short-term shareholders or long-term shareholders. Loyalty-promoting instruments intend to shield the board from 'faux' (i.e. intervention) voice, while facilitating 'true' (i.e. stewardship) voice. ${ }^{43}$ A recent paper by Fried gives an illustration of the relevance of this context-specific approach. ${ }^{44}$ Fried demonstrates that, in the case for favouring long-term shareholders, share repurchasing is an important factor to take into account. In a 'non-transacting' firm (i.e. a firm that does not repurchase its own shares or issue additional shares), long-term shareholders want managers to enhance long-term value and short-term shareholders might benefit from what Fried calls 'costly price-boosting manipulation' (i.e. boost short-term stock price at the expense of long-term shareholder value). Fried also shows that in a 'transacting firm' (i.e. a firm that buys or sells its own shares) long-term shareholders, like shortterm shareholders, may benefit from value-destroying actions. ${ }^{45}$ Thus, in 'transacting' firms, loyalty-promoting instruments might not have the intended effect of enhancing long-term shareholder value.

39. See, e.g., B.J. Bushee, 'The Influence of Institutional Investors on Myopic R\&D Investment Behaviour', 73 The Accounting Review 3 (1998) and N. Burns, S. Kedia and M. Lipson, 'Institutional Ownership and Monitoring: Evidence from Financial Misreporting', 16 Journal of Corporate Finance 443 (2010). See also Haldane and Davies, above n. 32

40. Bebchuk (2013), above n. 37, at 1.

41. Bebchuk (2013), above n. 37, at 12

42. Bebchuk (2013), above n. 37, at 18. See also M.P. Nieuwe Weme and G. van Solinge, 'Beschermingsmaatregelen tegen Vijandige Biedingen: Beperkingen en Mogelijkheden', Ondernemingsrecht 6 (2006), at 220 and infra Section 7.2.

43. See infra Section 3 on intervention, stewardship and 'faux' voice and infra Section 7 on loyalty-promoting instruments.

44. J.M. Fried, 'The Uneasy Case for Favoring Long-Term Shareholders', ECGI Working Paper Series in Law, No. 200 (2013).

45. Fried, above n. 44, concludes from his analysis of transacting and nontransacting firms that the case for shifting power from short-term to long-term shareholders is substantially weaker than it might appear. I would derive from Fried's analysis an argument against share repurchasing. See also A.W.A. Boot and K. Cools, 'Aandeleninkoop en Waardecreatie', 87 Maandblad voor Accountancy en Bedriffseconomie 5 (2013) (discussing share repurchasing at KPN, which did not result in enhancing long-term shareholder value) 


\section{Shareholder Activism}

In this article, the term shareholder activism has a broad meaning, as it is 'representing a continuum of responses to corporate performance'. ${ }^{46}$ This definition implies that - for the purpose of this article - the term is regarded in a much broader sense than shareholder activism by hedge funds. ${ }^{47}$ This narrow meaning of shareholder activism by hedge funds is regarded as only one type of shareholder activism.

In order to shed light on the different responses of shareholders to corporate performance, Hirschman's model of exit, voice, and loyalty is used. Exit, voice, and loyalty are regarded as different forms of shareholder activism. Other classifications of shareholder activism were possible. For instance, Michael Porter distinguishes between a 'quasi-indexer', 'transient', and 'dedicated' shareholder type. ${ }^{48}$ Furthermore, Winter identifies three different levels of intensity of shareholder activism: 'compliance', 'intervention', and 'stewardship'. ${ }^{49}$ However, as will be shown, these various classifications can all be traced back to the classic responses of Hirschman's model.

Quasi-indexers, who are characterised by highly diversified portfolios and low turnover, represent the compliance level of shareholder activism. ${ }^{50}$ This type only undertakes shareholder action to the extent that it is a legal requirement. Compliance refers to the minimum level of shareholder activism. 'Blindly' following the advice of a proxy solicitor provides an example of this kind of shareholder activism. ${ }^{51}$

Transient shareholders trade frequently and have a short-term focus. ${ }^{52}$ This type represents the intervention level of shareholder activism. It is the intermediate level, which implies incidental shareholder activism. The necessity of an intervention is mostly motivated by an opportunity to increase short-term shareholder value. ${ }^{53}$ Examples of this kind of activism include the Dutch cases of $A B N A M R O$, Stork and $A S M I .{ }^{54}$ At the

46. See for this definition S. Gillan and L.T. Starks, 'A Survey of Shareholder Activism: Motivation and Empirical Evidence', 2 Contemporary Finance Digest 3 (1998), at 11

47. Van Bekkum et al. include an example of this use of the term shareholder activism. See J. Van Bekkum, J.B.S. Hijink, M.C. Schouten and J.W. Winter, 'Corporate Governance in the Netherlands', 14 Electronic Journal of Comparative Law 3 (2010), at 3 ('Recent numbers indicate that as many as $70 \%$ of the shareholders of Dutch listed companies are foreign shareholders. This has made Dutch companies particularly vulnerable to shareholder activism by hedge funds [emphasis added]').

48. M.E. Porter, Capital Choices: Changing the Way America Invests in Industry (1992). This classification is for instance used in Bushee, above n. 39

49. Winter (2011b), above n. 33.

50. Bushee, above n. 39.

51. Winter (2011b), above n. 33

52. Bushee, above n. 39.

53. Winter (2011b), above n. 33.

54. Supreme Court of the Netherlands 13 July 2007, JOR 2007/178 (ABN $A M R O)$, Netherlands Enterprise Chamber (Ondernemingskamer) 17 January 2007, JOR 2007/42 (Stork) and Supreme Court of the Netherlands, 9 July 2010, JOR 2010/228 (ASMI). These cases are discussed in Van Bekkum et al., above n. 47. compliance and intervention levels, shareholders rely to a large extent on the exit option.

Dedicated shareholders, who monitor management and have large long-term holdings, represent the stewardship level of shareholder activism. This level goes another step further, in the sense that the engagement of shareholders is structural (i.e. not limited in time or to a certain problem). ${ }^{55}$ Winter's words capture this approach well:

The structural engagement is in fact there to add value to the investment in the long term; it is the crux of a different way of investing. Shares are held for longer periods and success is determined on a long-term basis. Not continuously using the exit option that the market offers requires greater involvement of the investor in the company, more understanding, more information, and exercising more influence to protect and increase the value of the investment [emphasis added]. ${ }^{56}$

Thus, stewardship is about engagement of shareholders with the corporation. An example of stewardship behaviour includes entering into a dialogue with the management of the corporation. This level of shareholder activism relates to the voice option of shareholders and requires loyalty.

\subsection{Exit}

Exit is the common response of many shareholders in public corporations. ${ }^{57}$ Exit occurs when shareholders sell their shares and do the Wall Street Walk (i.e. vote with their feet). For most shareholders, selling is the 'easy' option, the path of least resistance. ${ }^{58}$ Blockholders (i.e. large shareholders) are an exception, as they cannot readily sell their shareholdings without incurring a negative impact on the corporation's market value. ${ }^{59}$ This is also why it is argued that some large institutional shareholders find themselves in the role of 'reluctant activists'. ${ }^{60}$ They engage in activism because of the high costs associated with selling their shares. ${ }^{61}$

55. Stewardship has a narrow understanding based on The UK Stewardship Code, above n. 26. It has been argued that stewardship has its roots in theology; see, e.g., T. Thompson, Stewardship in Contemporary Theology (1960).

56. Winter (2011b), above n. 33, at 13

57. Hirschman (1970), above n. 2, at 33 and 76

58. Bolton and Samama, above n. 7, at 2 .

59. A. Shleifer and R.W. Vishny, 'Large Shareholders and Corporate Control', 94 Journal of Political Economy 3 (1986). See also the studies of Edmans and others, above n. 6 and above n. 17.

60. This term is coined by Pozen, see R.C. Pozen, 'Institutional Investors: The Reluctant Activists', 72 Harvard Business Review 1 (1994).

61. L. Verstegen Ryan and M. Schneider, 'The Antecedents of Institutional Investor Activism', 27 Academy of Management Review 4 (2002), at 556. See for recent numbers on institutional investing The City UK, Fund Management, November 2012, <http://www.thecityuk.com/ assets/Uploads/Fund-Management-2012.pdf> (last visited 31 Jan. 2013). 
Exit is strongly aligned to economic behaviour; it is associated with Adam Smith's invisible hand. ${ }^{62}$ As a corrective device, exit operates indirectly: namely, through the market, which makes the study of exit the domain of economists. If shareholders sell their shares, share prices fall, which would alert management to problems. The idea is that a credible threat of exit has a disciplining effect on management, as a share price decline influences for instance executive compensation, and makes the corporation vulnerable for a change in control (i.e. the market for corporate control). ${ }^{63}$

In one of his later works, Hirschman explains that Exit, Voice, and Loyalty was motivated by 'the excitement of discovering arguments against the axiom that competition (exit) is the unfailing and exclusive remedy against all ills of economic organization'. ${ }^{64}$ Today's corporate governance model still excessively relies on exit. ${ }^{65}$ As the Kay Reviem points out, the structure and regulation of equity markets overwhelmingly emphasise exit over voice. ${ }^{66}$ The problem with this overemphasis on the exit option is that the unsatisfied shareholder is replaced by another shareholder, which greatly reduces the impact of the exit option. ${ }^{67}$ In the literature, this kind of exit is called 'faux exit'. ${ }^{68}$ Moreover, the most informed shareholders are the first to exit, thereby removing voice from those who would have the most to say (i.e. the most informed shareholders). ${ }^{69}$ Shareholders who are provided with high liquidity (i.e. an easy exit option) have a reduced incentive to voice their concerns. From the shareholder perspective, there is in other words less need for voice when exit is available. Hirschman's intention was to bring out 'the hidden potential of whatever reaction mode is currently neglected' ${ }^{70}$ It has become clear that, in the context of corporate governance, the neglected response is shareholder voice, which will now be discussed.

62. Hirschman (1970), above n. 2, at 15-16 ('[Exit] is the sort of mechanism economics thrives on. It is neat - one either exits or one does not; it is impersonal; any face-to-face confrontation ... with its imponderable and unpredictable elements is avoided and success and failure of the organization are communicated by a set of statistics; and it is indirect any recovery on the part of the declining firm comes by courtesy of the Invisible Hand ....'). See above n. 15 for further reference to Adam Smith's work in connection to eclecticism.

63. The market for corporate control originates from H.G. Manne, 'Mergers and the Market for Corporate Control', 73 Journal of Political Economy 110 (1965). See also A. Admati and P. Pfleiderer, "The "Wall Street Walk" and Shareholder Activism: Exit as a Form of Voice', 22 Review of Financial Studies 7 (2009), Edmans (2009), above n. 6, and Edmans and Manso, above n. 17

64. A.O. Hirschman, The Passions and the Interests - Twentieth Anniversary Edition (1977), at xxi.

65. The overreliance on 'exit' was already the case in 'yesterday's' corporate governance. See Kostant, above n. 5, at 208.

66. Kay Review, above n. 1, at 21, quoted on the first page of this article.

67. In the words of Hirschman (1970), above n. 2, at 124: 'Exit, compensated as it is by entry, ceases to be a serious threat to deteriorating organizations'

68. Kostant, above n. 5 , at 205

69. Bolton and Samama, above n. 7, at 2: 'exit, which in the case of a firm means that an individual shareholder sells her shares before the crisis becomes fully apparent to others'.

70. Hirschman (1970), above n. 2, at 126.
3.2 Voice

The term voice has by its nature a political character. ${ }^{71}$ Where exit is 'neat', voice in contrast is often 'messy'. ${ }^{72}$ Voice requires the articulation of reasons and the defence of one's position. ${ }^{73}$ Voice means that shareholders exchange their views with the corporation. ${ }^{74}$ It involves interaction, a dialogue with the management of the corporation. Voice can be viewed as an attempt to change rather than to escape from an unsatisfactory situation, such as a decline in corporate performance. ${ }^{75}$ Shareholders can voice their concern in different forms, ranging from public interventions, such as shareholder proposals and voting at annual general meetings, filing shareholder-sponsored proxy proposals, or engaging in private negotiations via letter writing, meetings and telephone calls with chairmen, CEOs and CFOs. ${ }^{76}$ Voice thus includes formal mechanisms (e.g. voting) and informal mechanisms (e.g. private negotiations).

It was already recognised that if the performance of a corporation declines, most shareholders will opt for exit (i.e. sell their shares). Voice is not a likely strategy for most shareholders, because they bear the full costs of these forms of activism individually, while only benefiting from their activities relative to their stake in the corporation. ${ }^{77}$ Thus, it is financially more viable to exit or free ride on the voice activities of others. ${ }^{78}$

According to Hirschman, economists have largely ignored voice. Their main focus is on market forces (i.e. exit) while they leave non-market forces (i.e. voice) to political scientists. ${ }^{79}$ If Hirschman's work is applied to corporate governance, it is mostly used to underscore the preeminence of the exit option for shareholders, which explains the absence of voice (i.e. a positive explana-

71. Bottomley, above n. 12, at 147

72. Hirschman (1970), above n. 2, at 15-16.

73. Bottomley, above n. 12, at 148.

74. Kay Review, above n. 1, at 10 .

75. Hirschman (1970), above n. 2, at 30 ('[Voice is] any attempt at all to change, rather than to escape from, an objectionable state of affairs, whether through individual or collective petition to the management directly in charge, through appeal to a higher authority with the intention of forcing a change in management, or through various types of actions and protests, including those that are meant to mobilize public opinion').

76. M. Becht, J. Franks, C. Mayer and S. Rossi, 'Returns to Shareholder Activism: Evidence from a Clinical Study of the Hermes UK Focus Fund', 22 Review of Financial Studies 8 (2009). See also Edmans (2013), above n. 6. Shleifer and Vishny, above n. 59 refer to these informal negotiations as 'jawboning'.

77. A.R. Admati, P. Pfleiderer and J. Zechner, 'Large Shareholder Activism, Risk Sharing and Financial Market Equilibrium', 105 Journal of Political Economy (1994).

78. In the words of Huddart: 'Effective monitoring of management by shareholders is a public good whose costs are privately incurred'. See S. Huddart, 'The Effect of a Large Shareholder on Corporate Value', 39 Management Science (1993), at 1417. In the words of Bolton and Samama, above n. 7, at 2: 'The voice response is likely to be personally costly to the activist shareholder, while bringing uncertain rewards in the distant future, which moreover are shared equally by both active and passive shareholders'. This free-rider problem is also discussed in Edmans (2013), above n. 6, at 5 .

79. Hirschman (1970), above n. 2, at 19 puts it as follows: 'I hope to demonstrate to political scientists the usefulness of economic concepts and to economists the usefulness of political concepts. This reciprocity has been lacking in recent interdisciplinary work [emphasis in original]'. 
tion), instead of arguing why generating voice might be important (i.e. a normative statement). ${ }^{80}$ However, it has recently been argued that, while voice is individually more costly, it is collectively the better response for the corporation. ${ }^{81}$ This point is made for the true - i.e. stewardship level of - voice. Similar to the aforementioned faux exit, a kind of 'faux voice' can be identified. This type of voice relates to the intervention level of shareholder activism, which is based on self-interested behaviour on the part of shareholders (i.e. maximising short-term shareholder value). I suggest this kind of faux voice is also the reason it is sometimes argued that empowering shareholders is part of the problem rather than the solution. ${ }^{82}$ In terms of Hirschman's model, exercising voice might result in self-interested behaviour on the part of the shareholder if it is not accompanied by a sense of loyalty to the corporation. Therefore, the next section will emphasise the importance of Hirschman's concept of loyalty.

\subsection{Loyalty}

The core idea of Hirschman's model is the postulation of an essentially 'hydraulic relation' or 'seesaw pattern' between exit and voice. ${ }^{83}$ This is to say that the more easily available the exit option is, the less likely the voice possibility is exercised. ${ }^{84} \mathrm{In}$ one of his later works (i.e. in an analysis of the radical political changes in Germany of 1989), Hirschman reformulates his model of the interplay of exit and voice. According to Hirschman, the German case of 1989 has demonstrated that exit and voice 'worked in tandem and reinforced each other'. ${ }^{85}$

80. A similar point is made by Kostant, above n. 5, at 211. See for a prominent example of underscoring the pre-eminence of 'exit' in the corporate governance context: F.H. Easterbrook and D.R. Fischel, The Economic Structure of Corporate Law (1991), at 83 ('The greater the availability of the sale or exit option, the less desirable is the voting or voice option. .... It is difficult to imagine a more effective exit option than the market in shares')

81. Bolton and Samama, above n. 7, at 2. A similar point has been made by J. Charkham and A. Simpson, Fair Shares: The Future of Shareholder Power and Responsibility (1999), at 1.

82. For instance, this point has been made by Talbot, who argues that 'increased shareholder involvement is a retrograde step which will only exacerbate the problems created by previous governance perspectives orientated around shareholder interests'. See L.E. Talbot, 'The Coming of Shareholder Stewardship: A Contextual Analysis of Current AngloAmerican Perspectives on Corporate Governance', Warwick Law School Legal studies Research Paper, No. 22 (2010), at 2.

83. Hirschman (1970), above n. 2, at 34. A.O. Hirschman, 'Exit and Voice: An Expanding Sphere of Influence', Rival Views of Market Society and Other Recent Essays (1986), at 91 and A.O. Hirschman, 'Exit, Voice, and the Fate of the German Democratic Republic: An Essay in Conceptual History', 45 World Politics 2 (1993), at 176. See also Kostant, above n. 5, at 211 and B. Hoffmann, 'Transnational Migration and Political Articulation: Making New Sense of "Exit and Voice"', COMCAD Working Papers, No. 47 (2008), at 5.

84. Hirschman (1970), above n. 2, at 43 ('The presence of the exit alternative can ... atrophy the development of the art of voice'), and Hirschman (1993), above n. 83, at 176 ('[T]he more pressure escapes through exit, the less is available to foment voice').

85. Hirschman (1993), above $n$ 83, at 177 . He became already aware of the complications of the seesaw relationship between exit and voice in 1986, when he noted that exit and voice are 'two basic, complementa$r y$ ingredients of democratic freedom, [they] have on the whole been enlarged or restricted jointly [emphasis added]'. See Hirschman (1986), above n. 83 , at 79 .
This reformulation of Hirschman's model is also relevant for the corporate governance context. Recent studies in corporate governance discuss the complementarity between exit and voice, by arguing that the option to exit makes voice more effective. ${ }^{86}$ However, these studies do not include the concept of loyalty in their analysis. Hirschman introduced the concept of loyalty in order to understand the interplay between exit and voice. In the context of the public corporation, loyalty means that shareholders hold their shares. They do not undertake any action; they neither sell their shares (i.e. exit) nor enter into a dialogue with the management of the corporation (i.e. voice). In this sense, in which loyalty is viewed as the default option (i.e. doing nothing), it could be argued that loyalty does not necessarily require an active, conscious decision.

In his original work, Hirschman's concept of loyalty already required a rational decision. He referred to loyalty as calculated behaviour. ${ }^{87}$ A loyal shareholder holds his shares based on 'the expectation that, over a period of time, the right turns will more than balance the wrong ones'. ${ }^{88}$ In this view, loyalty influences the balance between exit and voice. On the one hand, loyalty postpones exit. A loyal shareholder will be less likely to sell his shares in the corporation. However, too much loyalty can result in a situation in which the exit option is 'unduly neglected' ${ }^{89}$ This is what Hirschman in one of his later works calls unlimited or 'blind' loyalty. ${ }^{90} \mathrm{On}$ the other hand, Hirschman argues that loyalty, by postponing exit, activates voice. ${ }^{91}$ This may save corporations from 'the dangers of excessive or premature exit'. ${ }^{92}$

86. See, e.g., D. Levit, 'Soft Shareholder Activism', Working Paper University of Pennsylvania (2013), at 4 and Edmans (2013), above n. 6, at 11.

87. This is what Williamson calls 'calculativeness'. See O.E. Williamson, 'Calculativeness, Trust, and Economic Organization', 36 Journal of Law and Economics 1 (1993). See on this also Kostant, above n. 5, at 234-235.

88. Hirschman (1970), above n. 2, at 78.

89. Hirschman (1970), above n. 2, at 92 (Making it 'possible for loyalty to overshoot the mark and thus to produce an exit-voice mix in which the exit option is unduly neglected'). If 'loyalty' overshoots the mark, it puts a brake on 'exit', while not activating 'voice'.

90. See A.O. Hirschman, 'Exit and Voice, An Expanding Sphere of Influence' in Rival Views of Market Society and Other Recent Essays (1992), at 80-81.

91. It can be questioned whether loyalty really activates voice. A shareholder who is loyal to the corporation has not used the exit option, but this does not automatically imply that the shareholder will actually use his voice. He may also remain passive. In the literature, several writers have made this point. See, e.g., Fried, above n. 44, at 4 (' $[\mathrm{W}]$ e cannot count on shareholders to be better stewards of the firm simply because they hold their shares for a longer period of time [emphasis added]'). In the next pages, I will argue that loyalty is a precondition for voice. A certain level of loyalty is a necessary, but not sufficient condition for voice. Loyalty facilitates the voice option, but it does not in any sense 'force' a shareholder to perform voice activities. A loyalty-promoting instrument is not to be regarded as 'love for money', compare the title of a 2007 Eumedion conference on loyalty dividend, Z. Tali and F.J. de Graaf, 'Loyaliteitsdividend, Registratiedividend en Instititutionele Beleggers: "Vaste Relatie of Betaalde Liefde"', Ondernemingsrecht 45 (2007). See also C. Clottens, 'Over de Beloning van Trouwe Aandeelhouders', Tijdschrift voor Rechtspersoon en Vennootschap (2013), at 7, who refers in the subtitle of his article - with a question mark - to the 1964 Beatles' song 'Can't Buy Me Love'.

92. Hirschman (1970), above n. 2, at 92. 
Thus, loyalty is to be regarded as the critical variable, which mediates between exit and voice. ${ }^{93}$

In one of his later works, Hirschman relates loyalty to the concept of trust. ${ }^{94}$ Although he does not further elaborate on this point, I see two important implications of the reference to trust. First, linking loyalty to trust highlights a long-term aspect. There is an old Dutch saying, ascribed to the statesman Johan Rudolph Thorbecke, that trust comes on foot but leaves on horseback. Where exit relates to the short term (i.e. the focus on market liquidity), exercising voice requires building a long-term relationship between the shareholder and the corporation. ${ }^{95} \mathrm{~A}$ shareholder will not engage in a meaningful dialogue with the management of the corporation (i.e. voice) if he is ready to sell his shares (i.e. exit) and does not feel attached to the corporation (i.e. loyalty). Second, the reference to trust highlights the psychological dimension of the concept of loyalty. ${ }^{96}$ Where exit and voice in essence represent shareholder activities (i.e. selling of shares and engaging in a dialogue with the corporation), loyalty is passive (i.e. holding of shares; non-exit and non-voice). However, loyalty implies more than a passive shareholder attitude. The psychological dimension of the concept of loyalty is regarded as the mental state of a shareholder feeling attached to the corporation. ${ }^{97}$ It has been argued that in the case of a decline in corporate performance, a shareholder with a sense of loyalty is likely to exhibit behaviour in line with his role as owner (i.e. psychological ownership ${ }^{98}$ ) with an interest in the corporation's long-term performance rather than purely short-term financial benefits. ${ }^{99}$

In the literature, loyalty has never received the same prominence as exit and voice. ${ }^{100}$ In the corporate governance context, I would propose to enhance loyalty. In

93. Bolton and Samama, above n. 7, at 2 .

94. Hirschman (1992), above n. 90, at 80-81 ('I stressed the value of loyalty as a factor that might delay overrapid exit. ... This argument could be formulated in terms of the concept of trust. Absence of trust would make for excessive instability through massive desertions from organizations whose performance is declining. The presence of trust would counteract such instability; provided ... that is it not unlimited or "blind", it will help to enlist the voice of the organization's members in the tasks of recovery and reform'). In this respect, Hirschman refers to an early work on trust by B. Barber, The Logic and Limits of Trust (1983). See also Williamson, above n. 87, at 461, with reference to Hirschman's Exit, Voice, and Loyalty.

95. More recently, the reference to trust has been made in the Kay Review, above n. 1, at 21: 'We believe equity markets will function more effectively if there are more trust relationships which are based on voice and fewer trading relationships emphasising exit [emphasis added]', and by Fox and Lorsch: 'separating long-haul shareholders from the rest could enable more communication and trust between them and boards and managers [emphasis added]'. See J. Fox and J.W. Lorsch, 'What Good Are Shareholders?', 90 Harvard Business Review 48-57 (2012).

96. See on the psychological foundations of trust, e.g., J.A. Simpson, 'Psychological Foundations of Trust', 16 Current Directions in Psychological Science 5 (2007)

97. K. Sikavica and A. Hillman, 'Towards a Behavioral Theory of Corporate Ownership and Shareholder Activism', Academy of Management Annual Meeting Proceedings (2008)

98. The term 'psychological ownership' is explained further in Section 5.

99. Sikavica and Hillman (2008), above n. 97, at 15

100. In this respect, it is telling that the German translation of Hirschman's book from 1974 already omits 'loyalty' from the title, making it simply Abwanderung und Widerspruch. See Hoffmann, above n. 83, at 6 . recent years, we have seen initiatives that intend to stimulate a more long-term orientation of directors, such as lengthening vesting periods of share options and introducing claw-back provisions into executive compensation. ${ }^{101}$ However, as has been argued in the literature, such measures will only prove effective if there is alignment with the time horizon of shareholders. ${ }^{102}$ The introduction of loyalty-promoting instruments could be helpful for inducing a more long-term commitment on the part of shareholders.

In corporate law literature, the mixed character of the concept of loyalty (i.e. postponing exit as well as facilitating voice) is not always recognised. For instance, Michael Schouten focuses on a potential downside of stimulating loyalty that has received little attention, i.e. its reduction of the threat of exit. ${ }^{103}$ Schouten refers to the following quote of Hirschman:

Loyalty-promoting institutions and devices are not only uninterested in stimulating voice at the expense of exit: indeed they are often meant to repress voice alongside exit. While feedback through exit or voice is in the long-run interest of organization managers, their short run interest is to entrench themselves and to enhance their freedom to act as they wish, unmolested as far as possible by either desertions or complaints of members. ${ }^{104}$

However, loyalty has not only a downside. Hirschman argues on the same page in his book that loyalty may also strengthen voice. ${ }^{105}$ I suggest that a certain level of loyalty - in the aforementioned sense of facilitating voice - seems necessary for shareholders to become engaged with the corporation they invest in. ${ }^{106} \mathrm{~A}$ certain level of loyalty, presumed that it is not unlimited or blind ${ }^{107}$, is a precondition for voice. ${ }^{108} \mathrm{I}$ propose that instruments that intend to stimulate long-term (loyal)

101. See for the legal regime for claw-back provisions in the Netherlands: Parliamentary Proceedings II, 32512

102. Bolton and Samama, above n. 7. See on the short-termist pressure of shareholders Haldane and Davies, above n. 32, and Barton, above n. 32.

103. See M.C. Schouten, 'What Albert Hirschman Would Have Thought of "Loyalty Dividend"', The Defining Tension, No. 181 (2010), <http:// www .thedefiningtension .com/ 2010/ 11/ no -181 -what -albert hirschmann-would -have -thought-of-loyalty-dividend-.html> (last visited 31 Jan. 2013). See also M.C. Schouten, 'Why Governance Might Work in Mutual Funds', in The Decoupling of Voting and Economic Ownership (2012), at 210-211.

104. Hirschman (1970), above n. 2, at 92-93

105. Hirschman (1970), above n. 2, at 92 ('Loyalty has ... been hailed as a force which, in the act of postponing exit, strengthens voice and may thus save firms and organizations from the dangers of excessive or premature exit').

106. In the words of Hirschman (1970), above n. 2, at 77: '[T] he likelihood of voice increases with the degree of loyalty.'

107. Hirschman (1992), above n. 90. If loyalty is 'blind', the threat of exit, to which Schouten, above n. 103 refers, becomes implausible.

108. European Commission, 'Green Paper, The EU Corporate Governance Framework', April 2011, COM (2011) 164 final, at 11 ('Shareholder engagement is generally understood ... as an activity which improves long-term returns to shareholders. Therefore the Commission believes that it is primarily long-term investors who have an interest in engagement'). See also Winter (2011b), above n. 33, who states that shareholder engagement and short-termism are related. 
share ownership, such as loyalty dividend and loyalty warrants, should be assessed as instruments that may enhance loyalty and influence the balance between exit and voice in favour of voice.

It is important to note that not all shareholders participate in the corporation in the same way. ${ }^{109}$ In the aforementioned article on the radical political changes in Germany of 1989, Hirschman complicates the assumption that at any one time all members of an organisation should have the same degree of loyalty. He imagines an organisation with two very different kinds of members: those with a high degree of loyalty and those with little or none. He argues that both types will react differently to a deterioration: 'those who are unburdened by feelings of loyalty will be prone to exit, while the loyalists will resort to voice'. ${ }^{110}$ With reference to Hirschman's German background, the former are characterised as the Ausreiser and the latter as the Bleiber. ${ }^{111}$ Loyalty-promoting instruments intend to influence the balance between the Ausreiser (i.e. in the corporate governance context: short-term speculators) and Bleiber (i.e. buyand-hold investors) in favour of the Bleiber. ${ }^{112}$ The loyalty-promoting instruments are discussed in more detail in Section 7.

\section{Comparative Analysis: Corporate Governance and Corporate Law}

It has already been mentioned in the introduction that exit is linked to a corporate law $\&$ economics framework and voice to a corporate constitutional framework. This section elaborates on these two theoretical frameworks.

\subsection{Theoretical Frameworks}

\subsubsection{Corporate Lam E Economics}

Corporate law $\&$ economics is defined as the application of economic analysis to corporate law. ${ }^{113}$ In the corporate governance context, law \& economics has to be regarded as the mainstream framework. ${ }^{114}$ The term

109. Bottomley, above n. 12, at 14 ('I argue that corporate constitutionalism does not mean that each and every member must participate in the corporation, and nor does each participating member need to do this in the same way').

110. Hirschman (1993), above n. 83, at 197-198.

111. Id.

112. See, e.g., Fox and Lorsch, above n. 95, at 51 ('To provide adequate liquidity, an asset market needs lots of fickle short-term speculators. A market composed solely of buy-and-hold investors wouldn't be very useful. But a market composed mostly of short-termers presents its own problems. And short-termers have been taking over the stock market').

113. Law \& economics in general is defined as the economic analysis to any area of law. See Arcuri, above n. 10, at 60

114. See, e.g., D.M. Branson, "Corporate Governance "Reform" and the New Corporate Social Responsibility', 62 University of Pittsburgh Law Review (2001), at 619 ('Particularly in the corporate field, law and economics came to primacy. ... Every book and journal article in the corporate law field had to take an economics of law perspective if they were to succeed in the marketplace of ideas'). 'mainstream' is used here to present law \& economics as the prevailing corporate governance framework, as compared with other theoretical frameworks, such as corporate constitutionalism.

Within the law \& economics framework, it is also possible to draw a divide between mainstream and 'heterodox'. ${ }^{115}$ Mainstream corporate law \& economics is rooted in agency theory. ${ }^{116}$ An agency relationship is defined as 'a contract under which one or more persons - the principal(s) - engage another person - the agent to perform some services on their behalf which involves delegating some decision-making authority to the agent'. ${ }^{117}$ The relationship between the shareholders and the management of a corporation fits the definition of a pure agency relationship. ${ }^{118} \mathrm{~A}$ contractual relationship in which the agent (i.e. management) promises performance to the principal (i.e. shareholders) is subject to an agency problem (i.e. a potential conflict of interest between the agent and the principal). ${ }^{119}$ In comparing corporate law \& economics with corporate constitutionalism, reference is made to mainstream corporate law $\&$ economics. To be sure, the article argues for a heterodox law \& economics, which is open to corporate constitutional considerations.

\subsubsection{Corporate Constitutionalism}

As the meaning of 'corporate constitutionalism' might be less obvious than corporate law \& economics, I will elaborate briefly on this term. Constitutionalism is not used in the formal or technical sense with which constitutional lawyers are familiar. ${ }^{120}$ Constitutionalism is intended to draw attention to the political character of corporations. A corporation is a 'body politic' as it embodies a governance system. ${ }^{121}$ Furthermore, constitutionalism draws attention to the observation that the institutional structures of public corporations appear to converge in notable ways with the institutional structures of public

115. Arcuri, above n. 10, at 60 formulates 'mainstream' as based on neoclassical economics, with its emphasis on rationally behaving actors and focus on welfare maximisation, while she refers to 'heterodox' as open to pluralism in relation to the techniques of inquiry.

116. M.C. Jensen and W.H. Meckling, 'Theory of the Firm: Managerial Behavior, Agency Costs and Ownership Structure', 3 Journal of Financial Economics 4 (1976), at 310, E.F. Fama and M.C. Jensen, 'Separation of Ownership and Control', 26 Journal of Law and Economics 2 (1983), and K.M. Eisenhardt, 'Agency Theory: An Assessment and Review', 14 Academy of Management Review 1 (1989).

117. Jensen and Meckling, above n. 116, at 308.

118. Jensen and Meckling, above n. 116, at 309. It is questionable whether this is a purely 'positive' claim, see infra Section 7.

119. E.F. Fama, 'Agency Problems and the Theory of the Firm', 88 Journal of Political Economy 2 (1980), and R.R. Kraakman, P.L. Davies, H. Hansmann, G. Hertig, K.J. Hopt, H. Kanda and E.B. Rock, The Anatomy of Corporate Law, A Comparative and Functional Approach (2009), at 35.

120. Bottomley above n. 12 , at 15 .

121. Bottomley above n. 12, at 12. See already Eells (1962), above n. 17, at 10, and J. Pound, 'The Rise of the Political Model of Corporate Governance and Corporate Control', 68 New York University Law Review 1003 (1993). 
government. ${ }^{122}$ The term 'corporate governance' originally derives from an analogy between public government (the government of states) and the government of corporations. ${ }^{123}$ Many corporate law concepts thus have a constitutional connotation. Over time, a number of corporate legal scholars have referred to this constitutional character of corporate governance and corporate law. ${ }^{124}$ With regard to the role of shareholders in corporate governance, shareholder democracy and citizenship of shareholders have already been mentioned. Other examples include human rights of shareholders, ${ }^{125}$ protection of minority shareholders, ${ }^{126}$ and equal treatment of shareholders. ${ }^{127}$

Although some striking similarities exist between corporate governance and public governance, ${ }^{128}$ both 'politi-

122. See on this C. Coglianese, 'Legitimacy and Corporate Governance', 32 Delaware Journal of Corporate Law, 159-167 (2007). See for a criticism on the comparison between corporate governance and public governance U. Rodrigues, 'The Seductive Comparison of Shareholder and Civic Democracy', 63 Washington and Lee Law Review, 1389-1406 (2006).

123. M. Becht, P. Bolton and A. Roëll, 'Corporate Law and Governance', in A.M. Polinksy and S. Shavell (eds.), Handbook of Law and Economics 2 (2007), at 834. Richard Eells is regarded as the first author who used the term 'corporate governance' to denote 'the structure and functioning of the corporate polity'. R.S.F. Eells, The Meaning of Modern Business: An Introduction to the Philosophy of Large Corporate Enterprise (1960), at 108. See for the evolution of vocabularies of corporate governance W. Ocasio and J. Joseph, 'Cultural Adaptation and Institutional Change: The Evolution of Vocabularies of Corporate Governance, 1972-2003', 33 Poetics 163-178 (2003).

124. See for some notable examples A.A. Berle and G.C. Means, The Modern Corporation and Private Property (1932), at 357 ('The law of corporations ... might well be considered as a potential constitutional law for the new economic state ....'), M.A. Eisenberg, 'The Legal Roles of Shareholders and Management in Modern Corporate Decisionmaking', 5 California Law Review 1 (1969), at 4 ('Corporate law is constitutional law; that is, its dominant function is to regulate the manner in which the corporate institution is constituted, to define the relative rights and duties of those participating in the institution, and to delimit the powers of the institutions vis-à-vis the external world'), R.B. Thompson, 'Exit, Liquidity, and Majority Rule: Appraisal's Role in Corporate Law', 84 Georgetown Law Journal 1 (1995), at 1 ('In corporations, the most common collective entity in the private sphere, a parallel allocation [of power as in the public sphere] must be made. In this sense, corporate law is properly termed constitutional law').

125. Art. 1 of the First Protocol to the ECHR (protection of property) provides a salient example, as share ownership falls within the protection of this article. ECHR, 25 July 2002, JOR, at 111 (2003), and ECHR 7 November 2002, JOR, at 112 (2002). See on this Timmerman (2007), above n. 11, at 332. See also A.J.P Schild, De Invloed van het EVRM op het Ondernemingsrecht (2012).

126. See, e.g., Branson, above n. 114, at 621 ('Corporate law is like constitutional law with a small ' $c$ ' .... Just as the Bill of Rights protects minorities from the tyranny of the majority, corporate law sets limits upon how far a majority may impose its will upon the minority'), and A. Chander, 'Minorities, Shareholder and Otherwise', 113 The Yale Law Journal (2003), at 119 ('Both corporate law and constitutional law seek to order relations between heterogeneous persons who hold stakes in a shared enterprise').

127. In earlier work, I have used the decision model developed by the European Court of Justice in cases on discrimination (i.e. cases with a constitutional connotation) as a source of inspiration for assessing the principle of equal treatment of shareholders in corporate law. See A.A. Bootsma, Financiële Prikkels voor Aandeelhouders (2011).

128. Not only with respect to the role of shareholders as emphasised in this article but also in a broader sense. Think for instance of the 'checks and balances' that exist between management, board of directors, and general meetings of shareholders, which make us think of the separation of powers as formulated by Montesquieu. cal' systems differ in many significant ways. ${ }^{129}$ For that reason, corporations are regarded as political entities in their own right, as also indicated by the adjective 'corporate' in corporate constitutionalism. ${ }^{130}$ This implies that within the corporate context, constitutional values and ideas may have applications and consequences different than in other political contexts. ${ }^{131}$ In other words, corporate constitutionalism uses constitutional values and ideas as a source of inspiration for corporate governance, instead of directly applying concepts from the constitutional domain to the corporate governance domain.

\subsection{Conceptual Differences}

Table 1, without being exhaustive, highlights some of the main conceptual differences between corporate law \& economics and corporate constitutionalism with regard to corporate governance and corporate law in general. Furthermore, the table makes reference to a selection of authors that have engaged with each particular dichotomy. These general conceptual differences are discussed in order to understand the differences in shareholder role, as will be analysed in the next section.

\subsubsection{Corporate Governance}

Corporate law \& economics is based upon an economic model of corporate governance, while corporate consti-
129. See Rodrigues, above n. 122

130. Bottomley, above n. 12, at 12 .

131. Id. 
Table 1 Conceptual differences in emphasis between corporate lam $\mathbb{E}$ economics and corporate constitutionalism

\begin{tabular}{lll} 
Corporate law \& economics & Framework & Corporate constitutionalism \\
\hline - Economic & $\begin{array}{l}\text { Governance model (Eisenberg, 1983; Dal- } \\
\text { las, 1998) }\end{array}$ & \\
\hline - Contract & $\begin{array}{l}\text { Foundation of corporate governance } \\
\text { (Vanberg, 1992; Bottomley, 2007) }\end{array}$ & - Constitution \\
\hline - Efficiency, welfare & $\begin{array}{l}\text { Goal of corporate law (Kaplow and Sha- } \\
\text { vell, 2002; Timmerman, 2007) }\end{array}$ & - Legitimacy, justice \\
\hline - Facilitate & Function of corporate law (Eisenberg, & - Regulate \\
& 1999; Assink, 2010) &
\end{tabular}

(c) A.A. Bootsma

tutionalism is built upon a political governance model. ${ }^{132}$ The conceptual foundation of corporate governance is in the economic model contract. In this model, the contractual separation of corporate ownership from control is at the heart of corporate governance. ${ }^{133}$ From the contractual perspective, the firm ${ }^{134}$ serves as a nexus of contracts (i.e. as a set of contracts among factors of production). ${ }^{135}$ Corporate constitutionalism shifts the way of thinking about corporate governance to the corporate constitution. In this view, the corporation is not simply a nexus of contracting relationships between individual

132. See on the distinction between an economic and political model of the corporation M.A. Eisenberg, 'Corporate Legitimacy, Conduct and Governance - Two Models of the Corporation', 17 Creighton Law Review 1 (1983). See further L.L. Dallas 'Two Models of Corporate Governance: Beyond Berle and Means', 22 University of Michigan Journal of Law Reform 19 (1998), who advocates a 'power model' over the 'efficiency model' of the corporation.

133. Jensen and Meckling, above n. 116 were in 1976 the first to translate the separation of ownership and control in terms of a conflict of interest (i.e. an agency problem) between management (i.e control as agent) and shareholders (i.e. ownership as principal). However, they were not the first who noticed the underlying problem of separation of ownership from control. In their seminal article, Jensen and Meckling refer to a quote of Adam Smith (1776): 'The directors of such [joint-stock] companies, however, being the managers rather of other people's money than of their own, it cannot well be expected, that they should watch over it with the same anxious vigilance with which the partners in a private copartnery frequently watch over their own. Like the stewards of a rich man, they are apt to consider attention to small matters as not for their master's honour, and very easily give themselves a dispensation from having it. Negligence and profusion, therefore, must always prevail, more or less, in the management of the affairs of such a company.' One hundred and fifty-seven years after Adam Smith, A.A. Berle and G.C. Means, above n. 124, at 311-312 popularised the concept of separation of ownership from control: 'On the one hand, the owners of passive property, by surrendering control and responsibility over the active property, have surrendered the right that the corporation should be operated in their sole interest. ... At the same time, the controlling groups, by means of the extension of corporate powers, have in their own interest broken the bars of tradition which require that the corporation be operated solely for the benefit of the owners of passive property.'

134. Note that economists speak about the 'firm', while lawyers refer to the 'corporation' or the 'company'. These different terms indicate underlying conceptual differences; see Bottomley, above n. 12, at 19. Lawyers posit the corporation as a separate legal entity, while economists look through the legal entity and see only a nexus of contracting relationships. corporate actors. Where contractual relationships are aimed at maximising individual advantage, the constitution shifts the way of thinking to the coordination of interactions ${ }^{136}$ for a collective purpose. ${ }^{137}$

\subsubsection{Corporate Lam}

The two models of corporate governance lead to different normative evaluation criteria for corporate law. The evaluation criterion in the economic model is efficien$c y .{ }^{138}$ From this perspective, shareholder activism can be viewed as a means to improve the governance or performance of a firm through alleviating the agency problems (i.e. conflicts of interest between management and shareholders) that arise on account of the separation of

135. Jensen and Meckling, above n. 116, at 310. Jensen and Meckling have built on A.A. Alchian and H. Demsetz, 'Production, Information Costs, and Economic Organization', 62 American Economic Review 5 (1972) and the antecedents of their work are in R.H. Coase, 'The Nature of the Firm', 4 Economica, New Series, 16 (1937).

136. See on 'coordination interactions' R. Hardin, 'Why a Constitution?', in B. Grofman and D. Wittman (eds.) The Federalist Papers and the New Institutionalism (1989), at 101.

137. Bottomley, above n. 12, at 13

138. According to Kraakman et al., above n. 119, at 28-29, the overall objective of corporate law is 'to advance the aggregate welfare of all who are affected by a firm's activities, including the firm's shareholders, employees, suppliers, and customers, as well as third parties such as local communities and beneficiaries of the natural environment. This is what economists would characterize as the pursuit of overall social efficiency'. And further, 'We believe that this ... view is - and surely ought to be - the appropriate interpretation of statements by legal scholars and economists asserting that shareholder value is the proper object of corporate law.' Or to put it bluntly in the words of Kaplow and Shavell, above n. 11: 'Our thesis is that social decisions should be based exclusively on the welfare of individuals - and accordingly, should not depend on notions of fairness, justice or cognate notions' [emphasis in original]. Although Kraakman et al. call their approach 'functional' they admit that it would perhaps be more accurate to call our approach "economic" rather than "functional", though the sometimes tendentious use of economic argumentation in legal literature to support particular (generally laissez-faire) policy positions, as well as the tendency in economic analysis to neglect non-pecuniary motivations or assume an unrealistic degree of rationality in human action, have ... caused many scholars, - particularly outside the United States - to be as wary of "economic analysis" as they are of "functional analysis".' See Kraakman et al., above n. 119, at 4. Their approach echoes that taken by R.C. Clark, Corporate Law (1986), and Easterbrook and Fischel, above n. 80 (1991). 
ownership and control in public corporations. ${ }^{139}$ Dispersed shareholdings of public corporations, resulting in a separation of ownership and control, are regarded as an efficient form of ownership, since the primary role of shareholders is the provision of risk-bearing capital. ${ }^{140}$ The focus on efficiency is considered to advance overall social melfare. ${ }^{141}$ This focus on the aggregate level is in contrast to the corporate constitutional perspective, which is concerned with justice and fairness in concrete cases. ${ }^{142}$ Another conceptual difference related to the goal of corporate law is that corporate law \& economics is focused on efficient outcomes, while corporate constitutionalism, with its focus on legitimacy, is also concerned with the (formal and informal) processes by which these outcomes are reached. ${ }^{143}$ To give an example, corporate constitutionalism emphasises the separation of powers between management, shareholders and board of directors and procedures for hiring and firing directors (i.e. procedural legitimacy). ${ }^{144}$ These kinds of procedural aspects are regarded as constitutional constraints on corporations (much like a constitution places side constraints on the legislature). ${ }^{145}$

The economic model of corporate governance leads to an emphasis on the facilitative function of corporate law. Mainstream corporate law \& economics argues that corporate law is designed principally to facilitate the organisation of investor-owned corporations. ${ }^{146}$ By making the corporate form 'widely available and user-friendly corporate law enables entrepreneurs to transact easily through the medium of the corporate entity, and thus lowers the costs of conducting business'. ${ }^{147}$ From the facilitative perspective, corporate law consists of default rules. ${ }^{148}$ Corporate law provides a standard form contract, which gives corporate parties the freedom to adopt or to deviate from the standard form. ${ }^{149}$ Furthermore, the facilitative function of corporate law highlights that

139. See above n. 133 for further references to the separation of ownership and control.

140. Fama, above n. 119

141. Kraakman et al., above n. 119

142. See, e.g., Timmerman (2007), above n. 11

143. Bottomley, above n. 12.

144. Eisenberg (1983), above n. 132, at 3. According to Eisenberg, under what he calls the Political Model, the corporation is 'essentially a political institution. The corporation's legitimacy depends upon the extent to which it is governed by principles appropriate to a democratic state [emphasis added]'. And further, 'the corporation is legitimated only if its processes turn on democratic participation by ... constituency groups [emphasis added]'

145. Coglianese, above n. 122, at 162 speaks of side constraints. See also K Heine, 'Inside the black box: incentive regulation and incentive channeling on energy markets', Journal of Management and Governance 3 (2011).

146. Kraakman et al., above n. 119 , at 14

147. Id. at 2

148. Id., at 20. In the 2004 edition of their book, Kraakman et al. speak of 'off-the-shelf housekeeping rules'. See also Easterbrook and Fischel, above n. 80.

149. Branson, above note 114, at 618 (2001) quotes an illustrative statement of D.R. Fischel, "The "Race to the Bottom" Revisited: Reflections on Recent Developments in Delaware's Corporation Law', 76 Northwestern University Law Review 913, at 944 (1982) ('Apart from minimizing transaction costs and possibly facilitating the operation of market forces that discipline management, corporation law has little role to play'). individual shareholders are allowed to pursue their own interests or goals. ${ }^{150}$ Corporate constitutionalism highlights the regulatory function of corporate law, which puts more emphasis on the constraints that the constitution of the corporation entails. ${ }^{151}$ The constitutional constraints are found in corporate law. In Dutch corporate law, the open norm of reasonableness and fairness provides a prominent example of such a constitutional constraint. ${ }^{152}$ This view highlights the importance of having a corporate law that is constituted not only of default rules but also of mandatory rules, in order to protect the interests of corporate parties, such as shareholders, creditors and employees. ${ }^{153}$

\section{Comparative Analysis: Shareholder Role}

The conceptual differences between corporate law \& economics and corporate constitutionalism highlighted in the previous section have implications for the way of thinking about the shareholder role in corporate governance. These implications are summed up in Table 2.

\subsection{Corporate Law \& Economics}

In the corporate law \& economics framework, the shareholder-as-investor role is emphasised. ${ }^{154}$ In a publicly held corporation with dispersed shareholdings, shareholder passivity is regarded as inevitable. ${ }^{155}$ From this

150. This principle also has a long tradition in case law, see, e.g., M. Meinema, 'Mandatory and Non-Mandatory Rules in Dutch Corporate Law', 6 Electronic Journal of Comparative Law 4 (2002).

151. V.J. Vanberg, 'Organizations as Constitutional Systems', 3 Constitutional Political Economy 2 (1992), at 243.

152. See, e.g., Dutch Corporate Governance Code, <http:// www .corpgov .nl/document/ ?id=606> (last visited 31 Jan. 2013), at preamble no. 9 (2008) (' $[S]$ hareholders can give priority to their own interests with due regard for the principle of reasonableness and fairness. The greater the interest which the shareholder has in a company, the greater is his responsibility to the company, the minority shareholders and other stakeholders'). The principle of reasonableness and fairness is laid down in Art. 2:8 of the Dutch Civil Code (DCC). Recently, Wiek Slagter has argued that not individual shareholders but only the general meeting of shareholders is bound to the principle of reasonableness and fairness. See W.J. Slagter, 'De metamorfose van de aandeelhouder', Nederlands Juristenblad 1683 (2012). See for a different opinion J. Biesheuvel-Hoitinga, A.A. Bootsma and H.M. Vletter-van Dort, 'De Relatie tussen de Raad van Commissarissen en Aandeelhouders(vergadering) bij Beursvennootschappen', Ondernemingsrecht 153-162 (2012), and the response to Slagter by J.M. de Jongh, 'Aandeelhouders Gebonden aan Eisen van Redelijkheid en Billijkheid', Nederlands Juristenblad 2099 (2012)

153. See for the Netherlands Art. 2:25 DCC. See also L. Timmerman (2004), above n. 16

154. Bottomley, above n. 12. See on different shareholder roles J. Hill, 'Visions and Revisions of the Shareholder', 48 The American Journal of Comparative Law 39 (2000).

155. B.S. Black, 'Shareholder Passivity Reexamined', 89 Michigan Law Review 3 (1990), at 522 ('Most modern corporate scholars, especially those with a law-and-economics bent, accept shareholder passivity as inevitable. They rely on market forces, especially takeovers, to limit managerial discretion. The critics' claim, stripped to its essentials, is that shareholders don't care much about voting except in extreme cases and never will'). 
Table 2 Shareholder role in corporate law ES economics and corporate constitutionalism

\begin{tabular}{lll} 
Corporate law \& economics & Framework & Corporate constitutionalism \\
\hline - Investor & Shareholder role (Hill, 2000; Bottomley, & - Member \\
& 2007) & \\
\hline - Economic & Share ownership (Sikavica and Hillman, & - Psychological \\
& 2008)
\end{tabular}

(C) A.A. Bootsma

perspective, shareholders rely on market forces, such as the market for corporate control, to discipline the agents (i.e. management). Eugene Fama provides an example of this view, which Black calls the 'passivity story': 156

$[\mathrm{P}]$ ortfolio theory tells us that the optimal portfolio for any investor is likely to be diversified across the securities of many firms. Since he holds the securities of many firms precisely to avoid having his wealth depend too much on any one firm, an individual security holder generally has no special interest in personally overseeing the detailed activities in any firm. ... Thus, although an individual security holder may not have a strong interest in directly overseeing the management of a particular firm, he has a strong interest in the existence of the capital market which efficiently prices the firm's securities. ${ }^{157}$

The shareholder-as-investor role is related to an econom$i c$ conception of share ownership. Share ownership is viewed as nothing more than another contractual relationship among individuals within the nexus of contracts that constitutes the firm. ${ }^{158}$ The metaphor of ownership as a 'bundle of rights' is useful in this context. ${ }^{159}$ The value of share ownership is only based on the level of property rights held. ${ }^{160}$

The property rights of shareholders are created and defined by legal rules. ${ }^{161}$ Shareholders own a relatively small and well-defined subset of rights in public corporations. ${ }^{162}$ In this respect, three key rights are identified: (i) the right to share in dividend payments and in distri-

156. Black (1990), above n. 155, at 522 ('Collective action problems, which arise because each shareholder owns a small fraction of a company's stock, explain why shareholders can't be expected to care. I will call this view the "passivity story"').

157. Fama, above n. 119, at 291-292. In this quote, Fama refers to modern portfolio theory and the efficient market hypothesis. See for an assessment of these theories Winter (2011b), above n. 33.

158. Fama, above n. 119, Jensen and Meckling, above n. 116.

159. See already A. Corbin, 'Taxation of Seats on the Stock Exchange', 31 Yale Law Journal (1922), at 429 ('Our concept of property has shifted (...). "[P]roperty" has ceased to describe any res, or object of sense, at all, and has become merely a bundle of legal relations - rights, powers, privileges, immunities.' [emphasis in original]).

160. Sikavica and Hillman, above n. 97. See also Jensen and Meckling, above n. 116, at 307 who focus on 'the behavioral implications of the property rights specified in the contracts between the owners and managers of the firm [emphasis added]'.

161. D. Kang and A. Sorensen, 'Ownership Organization and Firm Performance', 25 Annual Review of Sociology (1999), at 126.

162. Sikavica and Hillman, above n. 97 , at 8. butions in liquidation of the corporation, (ii) the right to vote (in particular upon the election of directors and certain major corporate changes) and (iii) the right to information (in the form of inspection of corporate books and records). ${ }^{163}$

The economic conception of share ownership leads to a narrow understanding of shareholder activism. Although the rights of shareholders have increased in recent years (i.e. shareholder empowerment), ${ }^{164}$ they remain limited in scope. Shareholders will only engage in shareholder activism to the extent they have specific legal rights do to so (in accordance with the compliance level of shareholder activism). From this perspective, the focus is only on rights; shareholders owe the corporation no legal duties. ${ }^{165}$ Shareholders become active only if they are financially rewarded for doing so. They are at best reluctant activists. ${ }^{166}$ Shareholder influence, if present, is indirect, and is mediated by their votes at the shareholders meeting. ${ }^{167}$

\subsection{Corporate Constitutionalism}

From a corporate constitutional framework, the shareholder is considered to be a member of the corporation. ${ }^{168}$ Membership entails ideas of participation, identity, responsibility and obligation. ${ }^{169}$ The role of shareholder-as-member shifts from the external (market) context to the internal (organisational) context. The shareholder is part of a collective enterprise. ${ }^{170}$ Membership emphasises that the shareholder has not only a formal role (e.g. voting) but also an informal role (e.g. private negotiations with the corporation prior to the shareholders' meeting).

The membership role of shareholders can be linked to psychological ownership, a concept introduced to organi-

163. Clark, above n. 138, at 13. See for a comparative analysis of these rights Kraakman et al., above n. 119.

164. See for the Netherlands Arts. 2:107a, 2:114a, 2:118a, 2:135, 2:161a DCC (Act of 9 July 2004, Stb. 2004, 370).

165. Anabtawi and Stout, above n. 30, at 4.

166. Pozen, above n. 60.

167. Sikavica and Hillman, above n. 97.

168. The idea of a membership relation can also be found in Dutch corporate law. See, e.g., Van der Heijden/Van der Grinten, Handboek voor de Naamloze en de Besloten Vennootschap (1992), No. 131, at 148-149, and Van Schilfgaarde/Winter, Van de NV en de BV (2006), No. 1, at 2. 169. Bottomley, above n. 12

170. Id. 
sation theory by Pierce and colleagues. ${ }^{171}$ Psychological ownership is described as 'a cognitive-affective state that characterises the human condition'. ${ }^{172}$ It has been argued that ownership can have an economic as well as a psychological dimension at the same time. ${ }^{173}$ Shareholders with a high level of psychological ownership perceive the corporation to be part of the self. ${ }^{174}$ In the literature, a model has been proposed that predicts the form of activism (i.e. exit, voice, or loyalty) based on the level of economic and psychological ownership of a shareholder. ${ }^{175}$ Where the former type of ownership is based on financial incentives and equips shareholders with legal powers, the latter form of ownership determines the motivation of shareholders to act as owners of the corporation. ${ }^{176}$ A high level of economic ownership (the shareholder-as-investor) is associated with the exit option, while a high level of psychological ownership (the shareholder-as-member) is related to the voice option for shareholders.

\section{Integrated Analysis}

It is not useful to choose the one theoretical framework over the other. In order to understand shareholder activism in its full breadth and depth, the two frameworks are combined. Corporations can be characterised as political as much as economic institutions, corporate law serves both to facilitate and to regulate corporate behaviour, shareholders are at the same time investors in and members of the corporation, and so forth.

If we take a closer look, it becomes clear that the two frameworks represent two 'faces' of the same 'head' (i.e. the aforementioned Janus head of corporate law ${ }^{177}$ ). The two faces represent equivalent aspects of the same reali-

171. J.L. Pierce, L. Van Dyne and L. Cummings, 'Psychological Ownership: A Construct Validation Study', in M. Schanke (ed.), Proceedings of the Southern Management Association (1992), J.L. Pierce, T. Kostova and K. Dirks, 'Toward a Theory of Psychological Ownership in Organizations', 26 Academy of Management Review 2 (2001), and J.L. Pierce and L. Rodgers, 'The Psychology of Ownership and Worker-Owner Productivity', 29 Group and Organization Management 5 (2004).

172. J.L. Pierce, T. Kostova and K. Dirks, 'The State of Psychological Ownership: Integrating and Extending a Century of Research', 7 Review of General Psychology 1, at 84 (2003)

173. A. Etzioni, 'The Socio-Economics of Property', in F. W. Rudmin and C. Madera (eds.), To Have Possessions, A Handbook on Ownership and Property (1991), at 466 (Ownership is 'a dual creation, part attitude, part object, part in the "mind", part real').

174. Feike Sijbesma, CEO of Royal DSM NV, spoke on 8 November 2012 at an Eumedion conference about 'emotional' share ownership. See for a report from the conference <http:// www .eumedion .nl/ en/ news/ report_from_the_eumedion_conference _ _ _ know_ more_of_less companies_> (last visited 31 Jan. 2013).

175. Sikavica and Hillman, above n. 97.

176. Id.

177. See above n. 16 for further references on the Janus head of corporate law. ty. ${ }^{178}$ The literature provides a large number of illustrations of the fact that the difference between the two frameworks might be less than expected. For instance, Jensen and Meckling give an example of the distinction between property rights (highlighted by the corporate law \& economics framework) and human rights (highlighted by the corporate constitutional framework), by stating that property rights in fact are human rights. ${ }^{179}$ Vanberg gives another example by perceiving the corporate constitution as a social contract. ${ }^{180}$ Hijink argues that a certain level of protection of the interests of corporate actors such as creditors and employees (i.e. the regulatory function of corporate law highlighted by corporate constitutionalism) is a precondition for a facilitative corporate law (emphasised by law $\&$ economics). ${ }^{181}$ This section connects corporate law \& economics - with its emphasis on exit - and corporate constitutionalism with its emphasis on voice - by using the concept of loyalty. In Section 3, it has been mentioned that loyalty is not just the intermediate variable between exit and voice (i.e. loyalty as non-exit and non-voice). Loyalty determines the exit/voice mix. Loyalty has a psychological dimension (i.e. the mental state of a shareholder feeling attached to the corporation) and requires a long-term and trusting relationship between the shareholder and the corporation.

\subsection{Importance of Corporate Law}

The construction of loyalty as the variable that connects exit and voice highlights the importance of corporate law. In the introduction to this article, it was mentioned that where exit is the domain of economists and voice is the domain of political scientists, loyalty relates to the legal domain. The intrinsic character of law demands the balancing of diverging interests, which highlights a long-term perspective. This long-term perspective in the balancing of diverging interests can be found in the UK, Dutch and US corporate law. Since 2006, the UK Companies Act states that directors have a duty to promote the success of the corporation for the benefit of its members as a whole, and in doing so have regard (amongst other matters) to the likely consequences of any decision in the long term. ${ }^{182}$ In the Netherlands,

178. See for an example of an eclectic approach from another discipline R.G Dahrendorf, Class and Class Conflict in Industrial Society (1959), at 159. The sociologist Ralf Dahrendorf puts it as follows: '[l]n sociology (as opposed to philosophy) a decision which accepts one of these theories and rejects the other is neither necessary nor desirable. There are sociological problems for the explanation of which the integration theory of society provides adequate assumptions; there are other problems which can be explained only in terms of the coercion theory of society; there are, finally, problems for which both theories appear adequate. For sociological analysis, society is Janus-headed, and its two faces are equivalent aspects of the same reality'.

179. Jensen and Meckling, above n. 116, at 307 ('Property rights are of course human rights, i.e., rights which are possessed by human beings. The introduction of the wholly false distinction between property rights and human rights in many policy discussions is surely one of the all time great semantic flimflams').

180. Vanberg, above n. 151

181. Hijink, above n. 13.

182. See <http:// www .legislation .gov .uk/ ukpga/ 2006/46/ part/ 10/ data .pdf> (last visited 31 Jan. 2013). 
directors have a duty to act in the best interest of the corporation and its enterprise, which is understood to mean to act in the interest of all stakeholders. ${ }^{183}$ The Dutch Corporate Governance Code, revised in 2008, states that it is 'based on the principle accepted in the Netherlands that a company is a long-term alliance between various parties involved in the company' and emphasises that directors have a responsibility to weigh these various interests, with a view to 'ensuring the continuity of the enterprise, while the company endeavours to create long-term shareholder value'. ${ }^{184}$ Even in the US, most states permit directors to consider the interests of constituencies other than shareholders, and under Delaware law, directors have wide leeway to act in the long-term best interests of shareholders, even if that does not increase shareholder value in the short term. ${ }^{185}$ In the long term, the interests of shareholders and other constituencies of the corporations appear to converge. ${ }^{186}$

Corporate law thus requires directors to take a longterm perspective in their corporate actions. Feike Sijbesma, CEO of Royal DSM NV, a Dutch-based multinational life sciences and materials sciences company, describes the function of a corporation (and its CEO) in terms of the triple bottom line 'people', 'planet', and 'profit'. ${ }^{187}$ This is an interesting metaphor, as these three pillars to a certain extent correlate with shareholder activism in terms of the triad exit, voice and loyalty. Just as there has to be a balance between exit, voice and loyalty, the idea of the triple bottom line is that corporations need to attain a certain level of performance (i.e. the bottom line) in all three areas of people, planet and profit. ${ }^{188}$ Corporations have to strive for economic prosperity (i.e. profit), with due regard to the ecological (i.e. planet) and societal (i.e. people) impact of their actions. It will be clear that profit relates to the law $\&$ economics framework. Planet can be linked to the corporate constitutional framework, as it is concerned with how the outcome profit is reached. The ecological and societal

183. See Arts. 2:129 and 2:140 DCC. See also Van Bekkum et al., above n. 47, at 4 and the $A B N A M R O$ case, above n. 54.

184. See Dutch Corporate Governance Code, above n. 152, at 6 .

185. M.J. Roe, 'Delaware's Politics', 118 Harvard Law Review 2491, at 2525-2526 (2005), and Strine, above n. 25. The most prominent Delaware decision to this effect is Paramount Communications v. Time Inc., 571

186. The long-term enlightened shareholder value perspective is regarded as a 'third way', which merges shareholder and stakeholder elements. See, e.g., C.A. Williams and J.M. Conley, 'An Emerging Third Way?: The Erosion of the Anglo-American Shareholder Value Construct', UNC Legal Studies Research Paper, No. 04-09 (2004).

187. See, e.g., Sijbesma in his blog for the World Economic Forum, 'On the evolution of business', <http:// forumblog .org/ 2012/ 09/ on -the evolution-of-business/ > (last visited 31 Jan. 2013). The reference to Royal DSM NV is not accidental, as this corporation proposed a loyalty dividend, see infra Section 7.

188. The Triple Bottom Line originates from J. Elkington, Cannibalswith Forks: the Triple Bottom Line of 21st Century Business (1997). The triad 'people, planet, profit' was first coined by Elkington in 1995. Royal Dutch Shell adopted it as the title of its first sustainability report in 1997. impact of corporate actions can be viewed as constitutional constraints on profit. ${ }^{189}$

The balance between exit- and voice-related activities of shareholders is determined by corporate law. The term corporate law is used here in a broad sense, including securities regulation law, tax law and so on. Regulation of shareholder activism has been developed within the (mainstream) law \& economics framework, which puts considerable emphasis on the exit option for shareholders. In the literature, it is stated that regulation is based on the idea that 'there is no such thing as too much liquidity, too much trading, or too much volatility'. ${ }^{190}$ For the purpose of risk diversification, the legal framework compels shareholders to diversify their portfolios, which has led to 'an investment policy that is not focused on an actual understanding of individual companies, but on more or less following the market'. ${ }^{191}$ At this point, I recall the aforementioned citation of Fama. ${ }^{192}$ Consistent with this legal framework, shareholders have diversified their portfolios in large numbers. ${ }^{193}$

Tax law is also able to influence the exit/voice mix. For instance, in most countries short-term trading is subject to higher capital gains tax rates than long-term investing is, which discourages the exit option. ${ }^{194}$ Another muchdiscussed example includes a small tax on the selling of shares, referred to as the securities transaction tax or Tobin Tax. The idea of such a tax is also that it puts a brake on exit. ${ }^{195}$

Recently, the Dutch Parliament adopted new corporate governance rules (the Act Frijns), which entered into force on 1 July 2013. ${ }^{196}$ Although the exact issues with this act go beyond the purview of this article, the act provides a prominent example of the influence of corporate law on the voice option for shareholders. One of the key changes with regard to the Act is raising the threshold for the right of shareholders to submit items for the agenda of the general meeting from $1 \%$ to $3 \%$. This

189. See on constitutional constraints above n. 145

190. Fox and Lorsch, above n. 95 , at 52 .

191. Winter (2011b), above n. 33, at 6. Winter refers to the US Uniform Prudent Investor Act of 1995, <http://www.law.upenn.edu/bll/ulc/ fnact99/1990s/upia94.pdf> (last visited 31 Jan. 2013), and the EU Pension Directive (Directive 2003/41/EC of the European Parliament and of the Council of 3 June 2003 on the activities and supervision of institutions for occupational retirement provision), and EU Solvency II Directive (Directive 2009/138/EC of the European Parliament and of the Council of 25 November 2009 on the taking-up and pursuit of the business of Insurance and Reinsurance).

192. See Section 5, above n. 157

193. Winter (2011b), above n. 33, at 4 mentions some figures of large institutional shareholders ('The huge Norwegian state fund Norges Bank invests in 8,300 listed companies worldwide, the Californian pension fund Calpers invests in more than 7,700 companies, and the Dutch pension fund managers APG and PGGM each invest in more than 4,000 listed companies').

194. See Fox and Lorsch, above n. 95

195. See, e.g., Bolton and Samama, above n. 7, at 9 ('The financial transaction tax ... is partly motivated by this aspiration to curb speculation') and Fox and Lorsch, above n. 95, at 52 ('the possibility that [a financial transaction tax] would decrease liquidity should not be seen as a slamdunk argument against it'). A financial transaction tax was already proposed by John Maynard Keynes, see J.M. Keynes, The General Theory of Employment, Interest and Money (1936), at 105.

196. Act of 15 November 2012, Stb. 2012, 588. 


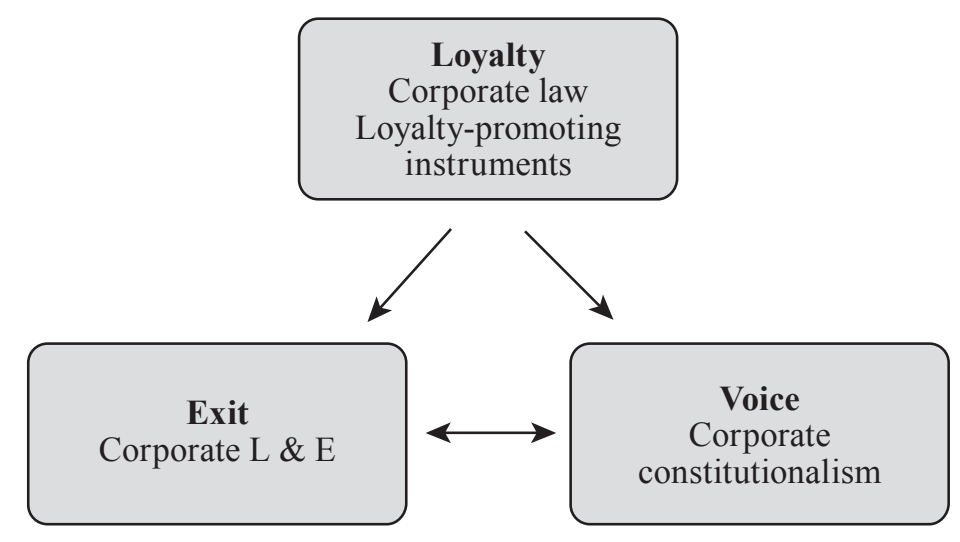

\section{(C) A.A. Bootsma}

change will have the effect of discouraging the voice option for shareholders as it becomes more difficult to submit items for the agenda. Furthermore, the Act introduces a regulation on the identification of shareholders of listed corporations. This change is aimed at enabling communication with shareholders prior to their general meeting (i.e. a measure aimed at stimulating shareholder voice).

It may seem counterintuitive to at the same time introduce measures which discourage and stimulate shareholder voice. The first measure, raising the threshold to submit items for the agenda, is a direct effect of the $A B N A M R O$ case ${ }^{197}$ in which hedge fund TCI, after acquiring only 1 or $2 \%$ of the shares of ABN AMRO, set in motion a string of events that ultimately led to a bailout of ABN AMRO by the Dutch government. In terms of Hirschman's model, the measure of raising the threshold from $1 \%$ to $3 \%$ is directed against 'faux' voice (i.e. the intervention level of shareholder activism), while the measure of enabling communication with shareholders is aimed at the 'true' voice (i.e. the stewardship level of shareholder activism). ${ }^{198}$

\subsection{Interaction Between Exit, Voice and Loyalty}

The interaction between exit, voice and loyalty is illustrated in Figure 1. The boxes for exit, voice and loyalty have the same size and distance, which demonstrates that they are viewed as equally important. Loyalty is depicted at the top of the figure, as it influences both exit and voice. Furthermore, the figure makes reference to the underlying theoretical frameworks of corporate law \& economics and corporate constitutionalism, both of which are used to analyse corporate law. Corporate law \& economics and corporate constitutionalism are regarded as two different 'lenses' that look at the same reality. ${ }^{199}$ Each lens has a different emphasis, which results in different policy implications. An exclusive focus on corporate law \& economics underemphasises corporate constitutional aspects and vice versa.

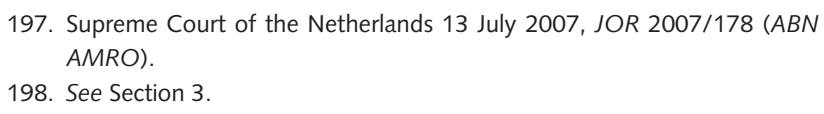

An exclusive focus on any one of these perspectives can have detrimental societal effects. It is recognised that the private constitutional contract (corporate governance) and the public constitutional contract (corporate law) remain incomplete. ${ }^{200}$ Corporate governance and corporate law leave discretionary room to decision makers. Directors can use this discretionary room in their own interest, which might not be in the interest of the shareholders, the corporation or society at large. ${ }^{201}$ The disciplinary mechanisms based on the law \& economics framework, such as the market for corporate control, are not able to prevent governance and financial crises, as mentioned in Section 2.

However, it must be considered that a certain level of discretion is necessary to facilitate entrepreneurship. ${ }^{202}$ Managerial discretion is needed to innovate and to be able to respond quickly to changing economic circumstances. ${ }^{203}$ These elements might be lost if corporate law and governance become overly focused on legitimacy on the basis of corporate constitutionalism. Governments, for instance, are often criticised for their 'sluggishness and gridlock' ${ }^{204}$ I agree with Coglianese that 'few proponents of current corporate governance reforms would advocate making corporations fully as rule-bound and democratically open as government is'. ${ }^{205}$

On the basis of the eclectic approach, I would argue for a balance between corporate law \& economics and corporate constitutional considerations. In the terminology of Hirschman, there is a need for a balance between exit and voice. Loyalty is the instrument to influence the exit/voice mix. Corporate law is not able to prescribe an

200. Easterbrook and Fischel, above n. 80, H. Hansmann, 'Corporation and Contract', 8 American Law and Economics Review 1-19 (2006), and Heine, above n. 145.

201. Heine, above n. 145.

202. See, e.g., Assink, above n. 16.

203. Coglianese, above n. 122.

204. In this respect, Coglianese refers to J. Rauch, Demosclerosis: The Silent Killer of American Government (1995). See Coglianese, above n. 122, at 167.

205. Coglianese, above n. 122, at 167. 
optimal mix for exit and voice. ${ }^{206}$ However, corporate law can facilitate loyalty-promoting instruments, which are analysed in the next section from a corporate law $\&$ economics and corporate constitutional perspective.

\section{Loyalty-Promoting Instruments}

7.1 Loyalty Dividend and Loyalty Warrants This final paragraph bundles the insights from previous sections to analyse loyalty-promoting instruments for shareholders in corporate law, such as loyalty dividends and loyalty warrants. Several French listed corporations make use of a loyalty dividend (prime de fidélité) for their long-term shareholders. ${ }^{207}$ In the Netherlands, Royal DSM made a proposal to amend its articles of association at the annual general meeting of 2007 in order to introduce a loyalty dividend. ${ }^{208}$ The proposal resulted in a legal case. Although DSM decided to withdraw the proposal to avoid a years-long conflict with a group of its shareholders, the Netherlands Supreme Court ruled 'in the interest of the law' that it is legally possible to introduce a loyalty dividend. ${ }^{209}$

In the literature, loyalty warrants have been proposed as a more flexible instrument compared with loyalty dividend. ${ }^{210}$ The idea of these instruments is that shareholders who hold their shares for a certain period of time (i.e. the loyalty period) are rewarded with a financial incentive, which could take the form of an addition-

206. Hirschman (1970), above n. 2, at 124 ('[A] word of caution is now needed about what our approach cannot yield: it does not come out with a firm prescription for some optimal mix of exit or voice, nor does it wish to accredit the notion that each institution requires its own mix that could be gradually approached by trial and error. At any point of time, it is possible to say that there is a deficiency of one or the other of our two mechanisms; but it is very unlikely that one could specify a most efficient mix of the two that would be stable over time. The reason is simple: each recovery mechanism is itself subject to the forces of decay which have been invoked here all along. This is so not just to add a final touch of philosophical consistency, but for more mundane reasons as well. As has already been mentioned, the short-run interest of management in organizations is to increase its own freedom of movement; management will therefore strain to strip the members-customers of the weapons they can wield, be they exit or voice, and to convert, as it were, what should be a feedback into a safety valve' [emphasis in original]).

207. Some examples include Air Liquide, Credit Agricole, Electricité de France and L'Oreal. See for the legal regime article L232-14 of the French Code de Commerce.

208. The aim of the loyalty dividend proposal was twofold: (i) create an incentive for shareholders who intend to keep their shares longer term (reward long-term shareholders) and (ii) improve the direct communication with these long-term shareholders.

209. See for the DSM case above n. 22. See further M.L. Lennarts and M.S. Koppert-van Beek, 'Loyalty Dividend and the EC Principle of Equal Treatment of Shareholders', 4 European Company Law, 173-180 (2008).

210. See Bolton and Samama, above n. 7. The instrument is also discussed in P.E. Masouros, Corporate Law and Economic Stagnation, How Shareholder Value and Short-termism Contribute to the Decline of Western Economies (2012), at 311-312, and A.A. Bootsma, 'L-warrants', in G.J. Meijer, P.M. Storm and L. Timmerman (eds.), Piet Sanders: een Honderdjarige Vernieuwer (2012), at 37-40. al dividend for the loyal shareholder or the form of a warrant attached to the share. Just like a share option, a warrant gives the right to purchase a pre-determined number of shares in the corporation at a pre-specified price. The dividend or warrant is granted to loyal shareholders on the expiration of the loyalty period, for instance a period of three years. $^{211}$

\subsection{Eclectic Approach}

The corporate law $\&$ economics and corporate constitutional framework highlight different aspects of loyalty dividend and loyalty warrants. From a corporate law $\&$ economics perspective, the loyalty-promoting instruments are regarded with suspicion. It is highlighted that the instruments can be used for intentions other than their initial purpose of stimulating loyalty. ${ }^{212}$ For instance, some authors have regarded the financial incentives as a 'stealthy' defensive measure to protect the board against a hostile takeover. ${ }^{213}$ Long-term shareholders would have an incentive to vote against a takeover of the corporation they invest in, in an effort to hold on their loyalty-promoting dividend or warrants. Another aspect emphasised from the law \& economics framework is that the instruments are sensitive to abuse by investors. Capital market developments have allowed investors to readily decouple legal share ownership from the economic interest attached to the shares. ${ }^{214}$ This decoupling makes it possible for shareholders who have no economic interest in the share to be registered for a loyalty dividend or warrant.

We must not ignore these objections to loyalty-promoting instruments. However, much will depend on their concrete implementation. With regard to the effect of loyalty warrants on the functioning of the market for corporate control, it should be noted that if a corporation underperforms, this will result in a decline in share price. In that case, the warrants will become 'out-of-themoney' (i.e. a strike price for the warrant that is higher than the price of the underlying share). The shareholder who was entitled to a loyalty warrant would then no longer have an incentive to hold the shares until the loyalty period expired. ${ }^{215}$ The loyalty of a shareholder who is entitled to a warrant thus is not unlimited or blind. Furthermore, the DSM case provides a possible solution with regard to shareholder abuse of loyalty dividend. The DSM board of directors was given a discretionary

211. A loyalty period of three years is used in France, and was also proposed by DSM. However, the loyalty period could be shorter or longer, depending on the particular circumstances of the corporation and its shareholders. See also Bolton and Samama, above n. 7, at 10.

212. This line of thinking is captured well by Schouten, above n. 103. In Section 3, I have already argued that this is only one side of the story. 'Loyalty' is also regarded as a precondition for 'voice'.

213. Nieuwe Weme and Van Solinge have discussed loyalty dividend as a new kind of defensive measure, see Nieuwe Weme and Van Solinge, above n. 42, at 220, and Paul Frentrop compared loyalty dividend to depository receipts for shares, see Tali and De Graaf, above n. 91.

214. See, e.g., H.T.C. Hu and B.S. Black, 'The New Vote Buying: Empty Voting and Hidden (Morphable) Ownership', 79 Southern California Law Review, at 811 (2006).

215. See Bolton and Samama, above n. 7, at 33-34 for the possible treatment of L-warrants in the case of a takeover. 
power to deregister shareholders who were suspected of misusing the instrument. ${ }^{216}$

Financial instruments such as loyalty dividend and loyalty warrants start from the (corporate law \& economicsbased) premise that incentives matter. ${ }^{217}$ The investment behaviour of shareholders is based on short-term profit maximisation. ${ }^{218}$ If we want long-term shareholder engagement to be more than rhetoric - or in the words of Adolf Berle, more than 'a pious wish that something nice will come out of it ${ }^{219}$ - the incentives of shareholders should be directed to the long term. ${ }^{220}$

Although the instruments start from the premise that incentives matter, they do not fit particularly well in law $\&$ economics-based agency theory. ${ }^{221}$ In fact, the agent (management) determines the desired (i.e. loyal) behaviour of the principal (shareholders). Some authors have questioned the normative neutrality of presenting the relationship between shareholders and management of the corporation as an agency relationship. ${ }^{222}$ Deciding who is to be regarded as the agent and who as the principal is already not normatively neutral. ${ }^{223}$ According to Heath, in agency theory the principal is understood as 'the one whose welfare ought to be served by the agent' (i.e. the managers ought to serve the interest of the shareholders). ${ }^{224}$ From a corporate constitutional perspective, the company is not viewed as a nexus of contracts (i.e. the 'firm') but as a separate legal entity (i.e. the 'corporation'). Management of the corporation has to take into account not only the interests of shareholders but also those of other constituencies. From this perspective, the introduction of loyalty-promoting instruments is less problematic, as management acts as repre-

216. See for the DSM case above n. 22

217. Kay Review, above n. 1, at 5 (2012) ('Incentives matter: not because, as some people crudely think, financial rewards are the only human motivating - although there are some people of whom that is true, and many of them are to be found in the financial sector'); Advocate-General Timmerman makes a similar point in his conclusion regarding the DSM case, above n. 22, at 3.58

218. S. Wong, 'Why Stewardship is Proving Elusive for Institutional Investors', Journal of International Banking and Financial Law (2010), at 406, Winter (2011b), above n. 33, at 9, and Walker Review, above n. 28, at 69.

219. A.A. Berle, 'For Whom Corporate Managers Are Trustees: A Note', 45 Harvard Law Review (1932), at 1368.

220. See, e.g., Sikavica and Hillman, above n. 97 who argue that the importance and priority attached to the long term is a result of shareholders' psychological ownership. See Winter (2011b), above n. 33, at 13 (2011b) for the link between shareholder 'stewardship' and a long-term perspective. See Bolton and Samama, above n. 7 for the relevance of alignment between the long-term horizon of the board and the shareholders.

221. For loyalty dividend, this was also recognised by F. Lute at the Eumedion seminar of 14 February 2007. The outcomes of this seminar are summarised in Tali and De Graaf, above n. 91. I have the papers of this seminar on file.

222. E.g., J. Heath, 'The Uses and Abuses of Agency Theory', 19 Business Ethics Quarterly 4 (2009), at 505 ('Jensen and Meckling present this as though it were purely an empirical observation - a "positive" claim about the structure of the firm, not a "normative" claim about how the firm should be organized. Yet it is not clear that describing a particular relationship as a "principal-agent" relationship can ever be normatively neutral').

223. Id

224. Heath, above n. 222, at 505-506. sentative of the corporation, which is a broader role than serving the interests of shareholders.

It has been argued that loyalty-promoting instruments granted with the 'right' motives - are not objectionable in themselves. ${ }^{225}$ These motives are to be found in the corporate constitutional framework. In the terminology of Hirschman, ${ }^{226}$ financial incentives for shareholders are intended to stimulate loyalty, in order to change the exit/voice mix in favour of voice. The incentives are an instrument to promote the stewardship level of shareholder activism (in the terminology of Winter) or to create more dedicated shareholders (in the terminology of Porter). ${ }^{227}$ In terms of share ownership types, the instruments try to stimulate a shift from economic ownership (i.e. the shareholder-as-investor) to psychological ownership (i.e. the shareholder-as-member). ${ }^{228}$

Financial incentives for shareholders are regarded as a private (market) solution to a problem of public interest. ${ }^{229}$ After the governance and financial crisis, the inability of institutional shareholders to become truly engaged shareholders in the long term has proven to be a fundamental corporate governance problem. As Winter points out, regulation is not able to address this underlying problem. ${ }^{230}$ He states,

A key challenge of regulation, in general, but certainly in response to a crisis, is to distinguish which problems can be meaningfully addressed by new regulation and which problems cannot. A bigger challenge still is to act on this distinction and to have the courage not to regulate the latter problems but to seek different avenues of addressing them. ${ }^{231}$

Loyalty-promoting instruments can be viewed as just such a 'different avenue'. The instruments provide a less radical and more flexible solution to the overemphasis on shareholder exit and an underemphasis on shareholder voice. The instruments are less radical than changes in the law, which require major interventions in capital markets (e.g. the aforementioned financial transaction tax). ${ }^{232}$ Furthermore, the instruments are more flexible, as corporate law only facilitates its introduction. The exact parameters of the instrument (e.g. the length of the loyalty period and the size of the dividend or strike price of the warrant) can be left completely or within certain legal boundaries up to the corporation, dependent on the particular circumstances of the corporation and its shareholder base. Based on the eclectic approach, the instruments combine the best of both worlds, by providing a law \& economics-based financial

225. R.H. Maatman, 'Integriteit van de Onderneming: Aandeelhouder en Integriteit', in I.P. Asscher-Vonk (ed.), Onderneming en Integriteit (2007), at 86 .

226. Hirschman (1970), above n. 2

227. Winter (2011b), above n. 33, and Porter, above n. 48

228. Sikavica and Hillman, above n. 97, and Bottomley, above n. 12

229. Maatman, at the Eumedion seminar, see Tali and De Graaf, above $n$. 91

230. Winter (2011a), above n. 32, at 14

231. Id.

232. Bolton and Samama, above n. 7, at 10. 
incentive to loyal shareholders in order to activate a true shareholder voice (i.e. a corporate constitutional motive).

\section{Conclusion}

In this article, Hirschman's model of exit, voice and loyalty has been used to analyse the corporate governance role of shareholders in public corporations. Although Hirschman wrote the original work Exit, Voice, and Loyalty more than forty years ago, the concepts are still very useful in the context of corporate governance. Applying Hirschman's model to shareholder activism exposes an excessive focus of shareholders on exit, which is accompanied by under-emphasising shareholder voice. $^{233}$

Loyalty is regarded as the critical variable, which mediates between exit and voice. In this article, the longterm and psychological dimension of loyalty has been highlighted. I have suggested that instruments that intend to stimulate loyal share ownership, such as loyalty dividend and loyalty warrants, should be assessed as instruments that may influence the balance between exit and voice in favour of the voice option for shareholders. In the literature, this function of loyalty is not always recognised.

As regards loyalty-promoting instruments, several lessons are learned from revisiting Hirschman's model.

The first and second are taken directly from Hirschman. The third and fourth mentioned here are regarded as additions to Hirschman's model.

First, it is important to realise that every shareholder response has a shady side, which I have referred to as faux exit and faux voice. The shady side of loyalty is that it becomes unlimited or blind. In this case, loyalty no longer activates voice, but represses exit and voice. This lesson has to be taken into account in the concrete implementation of loyalty-promoting instruments. ${ }^{234}$

Second, in one of his later works, Hirschman has improved the model by complicating the assumption that at a given point all members of an organisation would exhibit the same level of loyalty. ${ }^{235} \mathrm{He}$ introduced Ausreiser (with a low level of loyalty) and Bleiber (with a high level of loyalty). In the context of corporate governance, these types can be translated to short-term speculators and buy-and-hold investors, respectively. This complication of the model is important, as it draws attention to the particular shareholder characteristics of the corporation. Introducing loyalty-promoting instruments will be most relevant for corporations with a large base of Ausreiser shareholders, which resort to exit. For such a corporation, the introduction of a loyalty dividend or loyalty warrant could result in a group of stable,

233. This analysis has recently been confirmed by the Kay Review, above $n$ 1.

234. See above n. 215 for the ability of loyalty warrants to cope with this problem.

235. Hirschman (1992), above n. 90 long-term shareholders, thereby creating a better balance between short-term speculators (i.e. liquidity) and buy-and-hold investors (i.e. stability) ${ }^{236}$ For a corporation with a founding or family business shareholder, there might be less reason to introduce loyalty-promoting instruments. ${ }^{237}$

The third lesson refers to the time horizon of corporate directors and shareholders. It is important that alignment exists between the time horizon of corporate directors and shareholders. It has been argued that measures that induce a more long-term orientation for corporate directors will only prove effective if they are accompanied by a long-term focus for shareholders. For shareholders, loyalty-promoting instruments try to induce a shift to the long term.

A fourth and final lesson is the importance of corporate law in relation to Hirschman's loyalty. Where exit is related to a corporate law \& economics framework and voice to a corporate constitutional framework, loyalty is related to corporate law. Corporate law balances the diverging corporate law \& economics and corporate constitutional considerations. Several examples have been provided on the influence of corporate law (in a broad sense) on the exit/voice mix. Loyalty-promoting instruments, which can be facilitated by corporate law, provide long-term shareholders with corporate law \& economics-based financial incentives. The instruments are based on corporate constitutional considerations and are intended to promote the stewardship level of shareholder activism and to create more dedicated shareholders. The instruments try to facilitate a shift from economic ownership (i.e. the shareholder-as-investor) to psychological ownership (i.e. the shareholder-as-member).

In summary, the eclectic approach to loyalty-promoting instruments for shareholders has demonstrated that (i) the corporate law \& economics and corporate constitutional framework highlight different aspects of the same reality (as a representation of the Janus head of corporate law); (ii) it is possible to combine the two frameworks in an eclectic analysis of loyalty-promoting instruments; and (iii) the eclectic approach leads to a more complete understanding of loyalty-promoting instruments than a one-sided analysis based solely on corporate law \& economics or corporate constitutionalism.

236. See for a similar point J.M. de Jongh, 'Loyaal aan Duurzame Waardecreatie', Ondernemingsrecht (2010), 152 (in response to Schouten, 2010, above n. 103).

237. Think also of the case of transacting firms as discussed by Fried, above n. 44. 